\title{
Abnormalities of Polymorphonuclear Leukocyte Function Associated with a Heritable Deficiency of High Molecular Weight Surface Glycoproteins (GP138): Common Relationship to Diminished Cell Adherence
}

Donald C. Anderson, Frank C. Schmalstieg, M. Amin Amaout, Steve Kohl, Michael F. Tosi, Nava Dana, Greg J. Buffone, Bonnie J. Hughes, B. R. Brinkley, William D. Dickey, Jon S. Abramson, T. Springer, Laurence A. Boxer, J. M. Hollers, and C. Wayne Smith Departments of Pediatrics, Microbiology and Immunology, Cell Biology and Pathology, Baylor College of Medicine, Houston, Texas 77030; Departments of Pediatrics, University of Texas Health Science Center, Galveston, Texas 77550; and the Department of Pediatrics and Program in Infectious Diseases, University of Texas Medical School, Houston, Texas 77025; Department of Pediatrics, Bowman Gray School of Medicine, Winston-Salem, North Carolina 27103; Department of Pediatrics, University of Michigan School of Medicine, Ann Arbor, Michigan 48109; Department of Pediatrics and the Dana Farber Cancer Institute, Harvard Medical School, Boston, Massachusetts 02115; Department of Anatomy, Michigan State University College of Human Medicine, East Lansing, Michigan 48823

bstract. Investigations of polymorphonuclear leukocyte (PMN) function were performed in a 5-yr-old white female with delayed umbilical cord separation, impaired pus formation, and a severe defect of PMN chemotaxis. Sodium dodecyl sulfate-polyacrylamide gel electrophoresis demonstrated an almost total deficiency of a high molecular weight glycoprotein(s) (GP138) in the granule and membrane fractions of the patient's cells, and $\mathrm{NaB}^{3} \mathrm{H}_{4}$-galactose oxidase labeling demonstrated the absence of a major glycoprotein complex on the surface of her PMNs. Monoclonal antibodies (MAb) were employed in flow cytometry experiments to demonstrate that two previously characterized glycoproteins (Mol and

This work was presented in part at the American Society for Cell Biology meetings in San Antonio, TX, 3 December 1983.

Address reprint requests to Dr. Anderson, Texas Children's Hospital, Infectious Diseases Section, Houston, TX.

Received for publication 12 September 1983 and in revised form 19 April 1984.

J. Clin. Invest.

(C) The American Society for Clinical Investigation, Inc.

0021-9738/84/08/0536/16 \$1.00

Volume 74, August 1984, 536-551
LFA1) were undetectable on the surface of the patient's PMNs and monocytes. Immunoprecipitation of ${ }^{125} \mathrm{I}$-labeled patient cells with subunit specific MAbs confirmed that the $\alpha$-subunits of Mol (155 kD) and LFA1 (177 kD) and their common $\beta$-subunit (94 kD) were totally deficient. Functional analyses of patient PMNs demonstrated severe impairment of adherence- and adhesion-dependent cell functions including spreading, aggregation, orientation in chemotactic gradients, antibody-dependent cellular cytotoxicity, and phagocytosis of particles (Oil-Red-0paraffin, zymosan) selectively opsonized with C3-derived ligands. Patient PMNs demonstrated a normal capacity to rosette with IgG or C3b-coated sheep erythrocytes, but rosette formation with $\mathrm{C} 3 \mathrm{bi}$-coated erythrocytes was profoundly diminished. Adhesion-independent functions including shape change, $N$-formyl-methionyl-leucyl- ${ }^{3} \mathrm{H}$ phenylalanine binding, and $\mathrm{O}_{2}^{-}$generation or secretion elicited by soluble stimuli were normal. Membrane fluidity, surface charge, and microtubule assembly were also normal. These findings provide new evidence that critical PMN surface glycoproteins are required to facilitate multiple adhesion-dependent cellular functions of the inflammatory response. 


\section{Introduction}

The delineation of a molecular basis for cell dysfunction in a limited number of primary neutrophil disorders has allowed unique and important contributions to our understanding of leukocyte biology (1). A clinical syndrome characterized by recurrent bacterial or fungal infection, progressive periodontitis, persistent leukocytosis, and/or delayed umbilical cord separation has been recently described in three children whose neutrophils demonstrated severely depressed adherence, chemotaxis, and phagocytic function, and a deficiency or absence of a particulate fraction glycoprotein (2, 3). Additionally, Arnaout et al. (4) reported studies in a male child with recurrent bacterial infections and diminished phagocytosis associated with a deficient granulocyte membrane glycoprotein (GP150). Further studies in that patient have demonstrated a severe deficiency of Mol (equivalent to OKM1) and LFA 1, two functionally related high molecular weight glycoproteins normally expressed on the polymorphonuclear leukocyte (PMN) surface (5).

Investigations described in this report have identified a total deficiency of PMN and monocyte Mol and LFAl in a female patient with a similar clinical syndrome (6). These studies were designed to explore the role of these glycoproteins in allowing normal PMNs to interact with experimental or biologic substrates, phagocytizable test particles, or the surfaces of other cell types, and to determine their topographical and/or functional relationships to selected PMN membrane receptors. Our findings provide new evidence that motile, phagocytic, and cytotoxic functions of PMN are linked to cell adhesive properties mediated by critical surface glycoproteins.

\section{Methods}

Isolation of PMN leukocytes. PMNs were purified from heparinized venous blood samples over Ficoll-Hypaque gradients and suspended in Dulbecco's phosphate-buffered saline (DPBS) ${ }^{1}$ (Gibco Laboratories, Grand Island Biological Co., Grand Island, NY), pH 7.4, containing $0.2 \%$ dextrose. Final PMN suspensions contained $>97 \%$ PMNs, minimal platelet contamination, and an erythrocyte:PMN ratio of $\leq 3: 1$. For use in chemiluminescence $(C L)$, aggregometry, sodium dodecyl sulfatepolyacrylamide gel electrophoresis (SDS-PAGE), or $N$-formyl-methionylleucyl- ${ }^{3} \mathrm{H}$-phenylalanine (f-Met-Leu- ${ }^{3} \mathrm{H}-\mathrm{Phe}$ ) binding studies, erythrocytes were eliminated by hypotonic lysis (7).

Preparation of membrane and granule-rich fractions. As described previously (2), PMNs $\left(10^{8}\right)$ were placed in $2 \mathrm{ml}$ of ice cold DPBS, 100

1. Abbreviations used in this paper: ACLB, albumin-coated latex bead; ADCC, antibody-dependent cellular cytotoxicity; C, complement; CF, chemotactic factor; $\mathrm{CL}$, chemiluminescence; DPBS, Dulbecco's phosphate-buffered saline; E, sheep erythrocytes; f-Met-Leu- ${ }^{3} \mathrm{H}$-Phe, $N$-formylmethionyl-leucyl- ${ }^{3} \mathrm{H}$-phenylalanine; FITC, fluorescein isothiocyanate; HSA, human serum albumin; HSV, herpes simplex virus; IF, immunofluorescence; MT, microtubules; NP-40, nonidet P-40; PAS, periodic acid-silver; PMA, phorbol myristate acetate; PMSF, phenylmethylsulfonylfluoride; SDS-PAGE, sodium dodecyl sulfate-polyacrylamide gel electrophoresis; ZAP, zymosan-activated plasma. $\mu \mathrm{l}$ of diisopropylfluorophosphate $(0.1 \mathrm{M}$ in ethylene glycol) was added, and the mixture incubated at $4^{\circ} \mathrm{C}$ for $30 \mathrm{~min}$. Cells were washed three times in DPBS, placed in $2 \mathrm{ml}$ of an ice cold solution of $0.34 \mathrm{M}$ sucrose and $3 \mathrm{mM}$ phenylmethylsulfonylfluoride (PMSF), and then broken in a teflon homogenizer. Broken cells were subjected to a brief low speed spin $(1000 \mathrm{~g})$ for $10 \mathrm{~min}$ to remove nuclei, unbroken whole cells, and membrane aggregates, and the supernatant was then centrifuged at 27,000 $g$ for $30 \mathrm{~min}$. The supernatant from the $27,000 \mathrm{~g}$ centrifugation was then subjected to centrifugation at $105,000 \mathrm{~g}$ for $1 \mathrm{~h}$.

Preparation of reagents. Stock solutions of f-Met-Leu-Phe (Sigma Chemical Co., St. Louis, MO) and f-Met-Leu- ${ }^{3} \mathrm{H}-\mathrm{Phe}$ (New England Nuclear, Boston, MA) were prepared in DPBS. A low molecular weight chemotactic factor (CF), referred to as complement C5a in this manuscript, was prepared from activated human sera as described (8). Neuraminidase from Vibrio cholerae (500 units/ml) was purchased from Schwarz/Mann (Orangeburg, NY). Galactose oxidase from Dactylium dendroides (Sigma Chemical Co.) was further purified by affinity chromatography over Sepharose (9). $\mathrm{NaB}^{3} \mathrm{H}_{4}$ was obtained from New England Nuclear. This material (sp act, $15 \mathrm{Ci} / \mathrm{mmol}$; total, $250 \mathrm{mCi}$ ) was dissolved in $2.5 \mathrm{ml}$ of $0.01 \mathrm{M} \mathrm{NaOH}$. Zymosan, calcium ionophore A23187, cytochalasin B, colchicine, fluorescein isothiocyanate (FITC)-concanavalin A, nonidet P-40 (NP-40), phorbol myristate acetate (PMA) (Sigma Chemical Co.), and rabbit anti-human serum albumin (HSA) (Calbiochem-Behring Corp., La Jolla, CA) were obtained commercially. Antilactoferrin and Anti-tubulin IgG were prepared as previously described $(10,11)$.

Monoclonal antibodies (Mab). The MAb to Mol was kindly provided by Dr. R. F. Todd III (12). The OKMI MAb was obtained from Ortho Pharmaceutical (Raritan, NJ). The TS1/2 MAb to LFA1- $\alpha$ and the TS1/18 MAb to the common $\beta$-subunit of LFA1 and Mo1/OKM1 were prepared as previously described (13). $\mathrm{F}\left(\mathrm{ab}^{\prime}\right)_{2}$ fragments of $\mathrm{IgG}_{2}$ antiMol were prepared by pepsin digestion (14). A F $\left(a^{\prime}\right)_{2 a}$ fragment of rabbit IgG directed against the human $\mathrm{C} 3 \mathrm{~b}$ receptor (anti-CR1) was a generous gift of Dr. D. Fearon, Harvard Medical School, Boston, MA (15).

SDS-PAGE. SDS-PAGE was performed as described by Laemmli (16) using both $2.5 \times 110$-mm cylindrical gels or $5 \times 120 \times 140$-mm slab gels. For whole cells preparations, $2 \times 10^{7}$ cells were treated with diisopropylfluorophosphate and solubilized in $0.2 \mathrm{ml}$ of $1 \% \mathrm{NP}-40$ containing 2 mM PMSF (2). PMN granules or membranes were placed directly in SDS containing sample buffer. Cylindrical gels were stained with a $10 \%$ perchloric acid solution of Coomassie Blue G. Slab gels were stained with Coomassie Blue R-250 or silver. Periodic acid-silver (PAS) stains of carbohydrates were also performed (17).

Surface labeling of PMN glycoproteins. PMNs $\left(2 \times 10^{7}\right)$ were simultaneously treated with $0.025 \mathrm{ml}$ of neuraminidase (5 units) and $0.025 \mathrm{ml}$ of galactose oxidase (12.5 units) in $1 \mathrm{ml}$ of DPBS (18). Although neuraminidase treatment can decrease resolution in subsequent SDSPAGE, efficient labeling of the deficient surface glycoprotein requires this procedure. The cells were shaken gently on a $37^{\circ} \mathrm{C}$ water bath for $30 \mathrm{~min}$ and then washed twice and resuspended in $0.5 \mathrm{ml}$ of phosphatebuffered saline (PBS). $1 \mathrm{mCi}$ of $\mathrm{NaB}^{3} \mathrm{H}_{4}$ was added and the reaction was allowed to proceed for $30 \mathrm{~min}$ at $21^{\circ} \mathrm{C}$. Cells were collected by centrifugation and washed three times in DPBS. After solubilization of the cells in 1\% NP-40 and removal of nuclei and cell material by low speed centrifugation, the supernatant $(0.2 \mathrm{ml})$ was placed in SDS sample buffer, boiled for $2 \mathrm{~min}$, and subjected to SDS-PAGE. After SDS-PAGE, the gels were either stained with Coomassie-Blue $G$ or sectioned into $1.5-\mathrm{mm}$ slices, and the radioactivity was determined in a scintillation counter $(19,20)$. 
Flow cytometry immunofluorescence studies. Indirect immunofluorescence of intact PMNs was performed using MAbs and fluoresceinconjugated antimouse IgG or antigoat IgG $\mathrm{F}\left(\mathrm{ab}^{\prime}\right)_{2}$ as previously described $(21,22)$. Surface-stained PMNs were fixed in $1 \%$ paraformaldehyde and processed in a Coulter Epics V flow cytometer (Coulter Electronics, Inc., Hialeah, FL).

Immunoprecipitation studies. Intact PMNs were ${ }^{125} \mathrm{I}$-surface labeled with Iodogen (Pierce Chemical Co., Rockford, IL) as described (5). After labeling, cells were solubilized in 0.5\% NP-40 in PBS and the lysates centrifuged at $105,000 \mathrm{~g}$ for $30 \mathrm{~min}$. Supernatants were precleared with immune complexes consisting of a control mouse MAb, rabbit IgG antimouse IgG, and heat-inactivated formalin fixed Staphylococcus aureus. Precleared lysates were then incubated for $12-16 \mathrm{~h}$ with the specific MAb. Rabbit antiserum to mouse Ig or a rat antimouse kappa chain MAb was added and incubation continued for $1 \mathrm{~h}$ at $4^{\circ} \mathrm{C}$, followed by $S$. aureus $\left(30 \mathrm{~min}, 4^{\circ} \mathrm{C}\right)$. The insolubilized immune complexes were washed four times with PBS containing $2 \mathrm{mM}$ PMSF and 0.1\% NP-40 and then extracted by boiling in Tris buffer, $\mathrm{pH}=6.8$, containing $2 \%$ SDS sulfate and 5\% 2-mercaptoethanol. Eluates were electrophoresed on polyacrylamide gels as described (16).

Motility assays. PMN motility into micropore filters was assessed by a modified Boyden technique (7). The distributions of cells within filters were evaluated with an Optomax Image Analyzer (Optomax, Inc., Hollis, $\mathrm{NH}$ ) at various times after loading the chemotaxis chambers, and the depths at which only two cells were in focus in one high power $(\times 40)$ field were measured after incubation periods of 40-60 min (23). Leukotactic indices were calculated as described (24).

Shape change assay. A modification of the method of Smith et al. (25) was utilized. Suspensions of PMNs were exposed to CFs under varying conditions and then fixed in cold $\left(4^{\circ} \mathrm{C}\right) 1.5 \%$ glutaraldehyde. Fixed cells were examined with a $\times 1000$ phase contrast objective and classified according to shape (25).

Adherence assays. Adherence chambers were assembled as described (25) after pretreatment of one of two cover glasses for $2 \mathrm{~min}$ with a solution of 6\% pooled human serum in DPBS. Each chamber was filled with a suspension of PMNs $\left(5 \times 10^{5} / \mathrm{ml}\right)$, which was allowed to settle onto the pretreated glass substrate undisturbed at $21^{\circ} \mathrm{C}$ for $500 \mathrm{~s}$. Chambers were then inverted for an additional $400 \mathrm{~s}$. Cells remaining attached to the substrate surface were counted in 15-20 high power $(\times 400)$ fields. Chambers were again inverted and cells adhering to the untreated glass surface were counted. Results were expressed as the percentage of PMNs adhering to the treated surface over the total number of cells counted (treated plus untreated surfaces). A previously described albumincoated latex bead (ACLB) binding assay was also employed to quantitate adherence and to assess the distribution of PMN adhesion sites (26).

Aggregometry. PMN aggregation was evaluated as described by Hammerschmidt et al. (27). In most experiments, PMNs were preincubated with cytochalasin B $\left(5 \mu \mathrm{g} / \mathrm{ml}, 15 \mathrm{~min}, 37^{\circ} \mathrm{C}\right)$. After $30 \mathrm{~s}$ of stirring, f-Met-Leu-Phe, A23187, or zymosan-activated plasma (ZAP) was added to $\mathrm{PMN}$ suspensions $\left(0.5 \mathrm{ml}, 10^{7} \mathrm{PMN} / \mathrm{ml}\right)$. PMN aggregate formation was confirmed by phase microscopy.

Spreading. The capacity of PMNs to anchor on plastic, glass, or HSA-anti-HSA-coated glass substrates was assayed as described $(2,3)$. Cells attached to these substrates were fixed in $2 \%$ glutaraldehyde and evaluated by phase-contrast or scanning electron microscopy.

Orientation in chemotactic gradients. Orientation chambers as described by Zigmond (28) were employed. PMN were allowed to attach to the center of glass cover slips pretreated with 5\% HSA for $10 \mathrm{~min}$ at $21^{\circ} \mathrm{C}$ before they were inverted over the chamber bridge. Adjacent wells were loaded with solutions of CFs or DPBS. Cells overlying the bridge were observed with a $\times 40$ phase objective between 30 and $60 \mathrm{~min}$ after loading the chamber wells with CFs.

Degranulation. To determine lysosomal granule protein content and release after stimulation, untreated PMNs $\left(10^{7} / \mathrm{ml}\right)$ or PMNs pretreated with cytochalasin $B\left(5 \mathrm{~g} / \mathrm{ml}, 5 \mathrm{~min}, 37^{\circ} \mathrm{C}\right)$ were stimulated in a shaking water bath with f-Met-Leu-Phe $(20 \mathrm{nM})$, PMA $(10 \mathrm{~g} / \mathrm{ml})$, or opsonized zymosan, and then centrifuged at $400 \mathrm{~g}$ for $5 \mathrm{~min}$ at $4^{\circ} \mathrm{C}$ (29). The cellfree supernatant fluids or cell pellets were then assayed for lysozyme (30), beta glucuronidase (31), lactoferrin (10), and the cytoplasmic enzyme, lactic acid dehydrogenase (32). Enzyme activities were expressed as a percentage of the total cell content released by stimulation as well as the total cell content of each enzyme.

Oxidative metabolic activity. Superoxide generation of PMNs exposed to PMA was quantitated employing a ferricytochrome $c$ reduction assay (33). The evolution of CL by PMNs before or after metabolic activation by f-Met-Leu-Phe, A23187, PMA, or opsonized zymosan particles was quantitated as previously described (34).

Phagocytosis assays. Phagocytosis of C3 or IgG opsonized emulsified paraffin oil droplets was measured as described by Stossel $(35,36)$. For selective C3 opsonization, serum obtained from a patient with severe combined immunodeficiency disease was utilized. Uptake of $\left[{ }^{14} \mathrm{C}\right] S$. aureus 502A was assayed as previously described (37). The rate of uptake of zymosan was calculated from the slope of CL evolution as previously described (34). Phagocytic ingestion of IgG opsonized ACLB (0.8 $\mu \mathrm{m})$ was evaluated in a similar CL assay. For these experiments, latex beads were exposed to $3 \%$ HSA for $2 \mathrm{~min}$, washed three times, and then exposed to a 1:10 dilution of rabbit anti-HSA $\left(30 \mathrm{~min}, 21^{\circ} \mathrm{C}\right)$.

Distribution of Fc receptors. Latex beads $(0.8 \mu \mathrm{m})$ were exposed to 3\% HSA for $2 \mathrm{~min}$, washed three times, and then exposed to a 1:10 dilution of rabbit anti-HSA $\left(30 \mathrm{~min}, 21^{\circ} \mathrm{C}\right)$. PMNs prestimulated with $1 \mathrm{nM}$ f-Met-Leu-Phe for $5 \mathrm{~min}$ at $37^{\circ} \mathrm{C}$ were then exposed to a $1 \%$ suspension of HSA-anti-HSA-coated latex beads containing $1 \mathrm{nM}$ f-Met-Leu-Phe for 10, 20, or 90 s prior to fixation in $1.5 \%$ glutaraldehyde. Bead binding distributions were identified by phase-contrast microscopy. HSA-coated latex beads exposed to anti-C 3 and beads treated only with HSA demonstrated no binding.

Rosetting assays. Sheep erythrocytes (E) were coated with rabbit IgG anti-E (EIgG), C3b (EAC3b), or C3bi (EAC3bi) as previously described in detail $(4,38)$. PMNs were kept at $4 \times 10^{6} / \mathrm{ml}$ in DPBS containing calcium and magnesium, $2 \mathrm{mg} / \mathrm{ml}$ bovine serum albumin, and $1 \mathrm{mg} / \mathrm{ml}$ soybean trypsin inhibitor (Millipore Corp., Bedford, MA). Cells $(25 \mu \mathrm{l})$ were incubated with $15 \mu \mathrm{l}$ of indicator sheep erythrocytes $\left(1.5 \times 10^{8} / \mathrm{ml}\right)$ in $1.5-\mathrm{ml}$ Eppendorf tubes, and the mixture was incubated in a water bath for $40 \mathrm{~min}$ at $37^{\circ} \mathrm{C}$. To assess rosette formation, cells were gently resuspended and examined using a hemocytometer. Binding of three or more sheep erythrocytes to a PMN was considered a rosette (4).

Antibody-dependent cellular cytotoxicity (ADCC). ADCC to herpes simplex virus (HSV)-infected ${ }^{51} \mathrm{Cr}$-labeled Chang liver target cells was assessed as previously described $(39,40)$. PMNs were diluted to yield effector-to-target cell ratios of 30:1-100:1 in an 18-h cytotoxicity assay with a final anti-HSV human immune or nonimmune serum concentration of 1:20. A single cell agarose assay was also performed as described by Silva et al. (41). Unlabeled HSV-infected Chang liver target cells ( 2 $\times 10^{5}$ cells $\left./ 100 \mu \mathrm{l}\right)$ were incubated with PMNs (1:1, effector-to-target cell ratio). Slides of these mixtures were prepared using $1.0 \%$ agarose. After an 18-h incubation, these were stained with trypan blue and fixed in $0.5 \%$ formalin. For each coded slide assessed, 200 PMNs were counted to determine the number of PMNs binding to target cells and the percent of those which killed target cells (trypan blue exclusion). 
Tubulin immunofluorescence (IF) and concanavalin-A capping procedure. PMNs were processed for quantitation of cytoplasmic microtubules (MT) as previously described by Anderson et al. (42). Distributions of FITC-concanavalin A binding were assessed for both unstimulated PMN suspensions and those pretreated with colchicine or CF before their exposure to FITC-concanavalin A $(15 \mu \mathrm{g} / \mathrm{ml}, 10 \mathrm{~min}$ at $\left.37^{\circ} \mathrm{C}\right)(43)$.

f-Met-Leu- ${ }^{3} \mathrm{H}$-Phe binding. PMNs $\left(10^{8} / \mathrm{ml}\right)$, f-Met-Leu- ${ }^{3} \mathrm{H}-\mathrm{Phe}$, and cold f-Met-Leu-Phe were incubated in $200 \mu \mathrm{l}$ of DPBS at $0^{\circ}$ or $37^{\circ} \mathrm{C}$ as described (7). Reactions were terminated by rapid dilution in cold $\left(4^{\circ} \mathrm{C}\right)$ DPBS followed by filtration and washing $(5 \mathrm{ml}$, twice) of mixtures through Whatman GFC filters (Whatman Laboratory Products, Inc., Clifton, NJ). Filters were placed into $10 \mathrm{ml}$ Fluorosol Scintillation Cocktail (National Diagnostics, Inc., Somerville, NJ) and radioactivity was quantitated in a Packard Tri-Carb liquid scintillation spectrometer (Packard Instrument Co., Downers Grove, IL). Specific binding was defined as the total amount of f-Met-Leu- ${ }^{3} \mathrm{H}-\mathrm{Ph}$ minus that proportion nonspecifically bound (7).

Membrane fluidity and surface charge. Membrane fluidity of PMNs $\left(3 \times 10^{8} / \mathrm{ml}\right)$ was measured at $37^{\circ} \mathrm{C}$ using a Bruker ER-200D electron spin-resonance spectrometer equipped with a computer for signal averaging (USA Bruker Instruments, Inc., Billerica, MA), and $40 \mu \mathrm{M} 5$ doxyl stearic acid (Molecular Probes, Inc., Junction City, OR) as described (44). PMNs were stimulated with DPBS or $10 \mathrm{nM}$ f-Met-Leu-Phe for $10 \mathrm{~min}$ and the order parameter (S), a measurement of spin label order and motion, was calculated (44). Cell surface charge was measured as described (45) using a microscope-monitored calibrated electrophoresis apparatus (Grant Instruments Ltd., Cambridge, England). PMNs (5 $\left.\times 10^{6} \mathrm{PMN} / \mathrm{ml}\right)$ were incubated for $10 \mathrm{~min}$ with PBS or with f-MetLeu-Phe $(10 \mathrm{nM})$ plus cytochalasin B $(10 \mathrm{M})$. Cell mobility $(\mu \mathrm{m})$ was calculated as described for at least 20 cells of each suspension and the results were reported as micrometers per second per volt per centimeter (45).

Scanning electron microscopy. PMNs were fixed in a solution of $1.5 \%$ glutaraldehyde in DPBS for $1 \mathrm{~h}$, washed three times, and then dehydrated by a graded series of acetone washes. After drying in a Bowmar critical point drying apparatus (Bowmar Instrument Corp., Ft. Wayne, IN), samples were sputter coated with $8 \mathrm{~nm}$ gold palladium with a Denton Disk-1 apparatus (Denton Vacuum, Inc., Cherry Hill, $\mathrm{NJ}$ ) and examined with a JEOL $100 \mathrm{CX}$ electron microscope operating at $15 \mathrm{kV}$ (JEOL USA, Electron Optics Division, Medford, MA) (7).

\section{Results}

SDS-PAGE. Results of SDS-PAGE of patient, material, and control PMNs (whole cell NP-40 lysates) are shown in Fig. 1. In patient and maternal lysates, a protein or protein complex with an apparent molecular weight of $138 \mathrm{kD}$ ( $10 \%$ acrylamide gels) is severely deficient (less than $5 \%$ [patient] or $20 \%$ [mother] of mean values for eight adult controls) as estimated by direct elution of the band corresponding to GP138 in 25\% dioxane and spectrophotometric determination $(615 \mathrm{~nm})$ of the eluted dye (46). An identical SDS-PAGE experiment is shown in Fig. $1 B$ where carbohydrates have been stained with PAS. To determine the reliability of the molecular weight estimates from SDS-PAGE, PMN granules from control subjects were electrophoresed in acrylamide concentrations from 5 to $10 \%$; the molecular weight estimates of GP138 ranged from 130 to $229 \mathrm{kD}$.
A

B

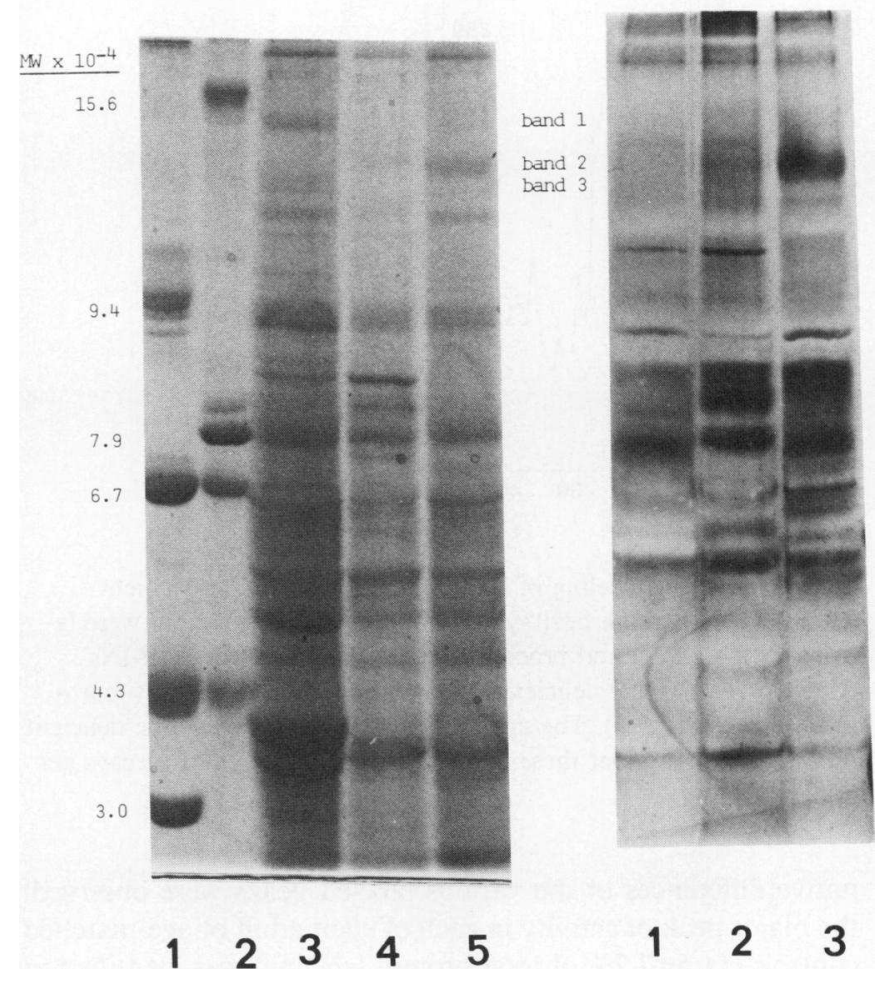

Figure 1. SDS-PAGE of PMN lysates. (A) SDS-PAGE was accomplished on 7.5 acrylamide gels stained with Coomassie Blue 6. Molecular weight (MW) standards (lane 1) include: phosphorylase b, 94 $\mathrm{kD}$; BSA, $67 \mathrm{kD}$; ovalbumin, $43 \mathrm{kD}$; and carbonic anhydrase, $30 \mathrm{kD}$. Additional standards in lane 2 include: human $\mathrm{IgG}, 156 \mathrm{kD}$; lactoferrin, $75 \mathrm{kD}$; BSA, $67 \mathrm{kD}$; and ovalbumin, $43 \mathrm{kD}$. Cell lysates of the patient (lane 3), the mother (lane 4), and a normal adult (lane 5) are shown. Band 1 (visible in patient) is a labile protein which could be demonstrated in both maternal and control lysates in other experiments. Band 2 (GP138) is the deficient protein identified. Band 3 was consistently present only in patient lysates. $(B)$ PMN lysates processed as in $(A)$ and stained with PAS are shown for the patient (lane 1), the patient's mother (lane 2), and a normal adult (lane 3). The deficient protein is virtually absent in the patient and quite deficient in the mother. The large carbohydrate content of this protein is evident in the normal.

A small but detectable increase in molecular weight was noted at each acrylamide concentration after reduction with 2-mercaptoethanol and the length of gels and total time of electrophoresis experiments caused additional variations in the estimates of molecular weight.

Labeling of surface glycoproteins. To confirm that the deficient protein was expressed on the cell surface, surface glycoproteins were labeled with $\mathrm{NaB}^{3} \mathrm{H}_{4}$ after neuraminidase treatment and oxidation with galactose oxidase (18) (Fig. 2). A major surface glycoprotein or protein complex was extremely deficient or totally absent in the patient's PMNs. Although some qual- 


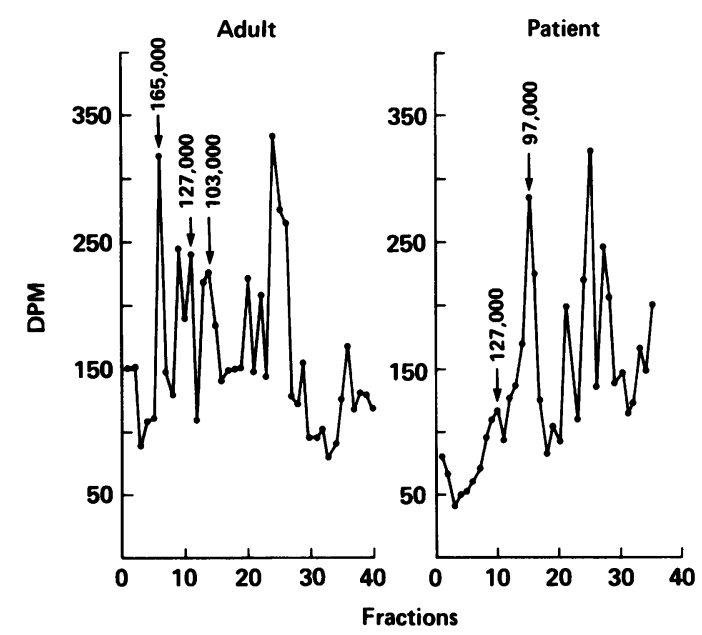

Figure 2. Surface labeling of healthy adult and GP138-deficient PMNs. PMNs from a healthy adult control and the patient were labeled with $\mathrm{NaB}^{3} \mathrm{H}_{4}$ and processed in SDS-PAGE. Patient PMNs demonstrate a severe deficiency of high molecular weight glycoprotein(s) (fractions 5-8). The apparent molecular weight of the deficient protein detected under these conditions is $165 \mathrm{kD}$. DPM, decays per minute.

itative differences of the various labeled peaks were observed, the major peak of activity in each of eight adult or age-matched controls $(11.5 \pm 7.2 \%$ of total protein labeling) was identified in fractions 5-8. Significantly reduced labeling of maternal cells was also observed (data not shown). Employing 7\% gels, the apparent molecular weight of the labeled protein was $165 \mathrm{kD}$. However, identical gels stained with Coomassie Blue $\mathrm{G}$ indicated that the deficient protein had a molecular weight of $145 \mathrm{kD}$. An explanation for this difference is uncertain, although it appeared to be unrelated to neuraminidase treatment.

Although increased proteolytic activity in the patient's cells or increased susceptibility to proteolysis by the patient's surface proteins cannot be rigorously excluded by these experiments, mixing of the patient's cells with normal cells did not decrease the amount of deficient protein added.

Analysis of cell surface antigens by flow cytometry immunofluorescence. As shown in Fig. 3, patient PMNs demonstrated no detectable surface OKM1/Mol- $\alpha$, LFA1- $\alpha$ or $\beta$, but did express normal amounts of other antigens including $C R 1$ and J5 (data not shown). Diminished amounts of OKM1- $\alpha(40 \%)$ and $\beta(60 \%)$ were detectable on the surface of the mother's PMNs (data not shown).

Immunoprecipitation of PMN membrane proteins by monoclonal antibodies. MAbs to the $\alpha$ - and $\beta$-subunits of Mo1, OKM1, and LFA1 were employed to immunoprecipitate these glycoproteins of from ${ }^{125}$ I-labeled normal PMNs as previously described $(4,47,48)$. Employing the same MAbs, no detectable bands were immunoprecipitated from patient ${ }^{125}$ I-labeled PMNs (data not shown), thus confirming the impaired assemblage of OKM1, Mol, and LFA1 on the surface of her PMNs. Further,

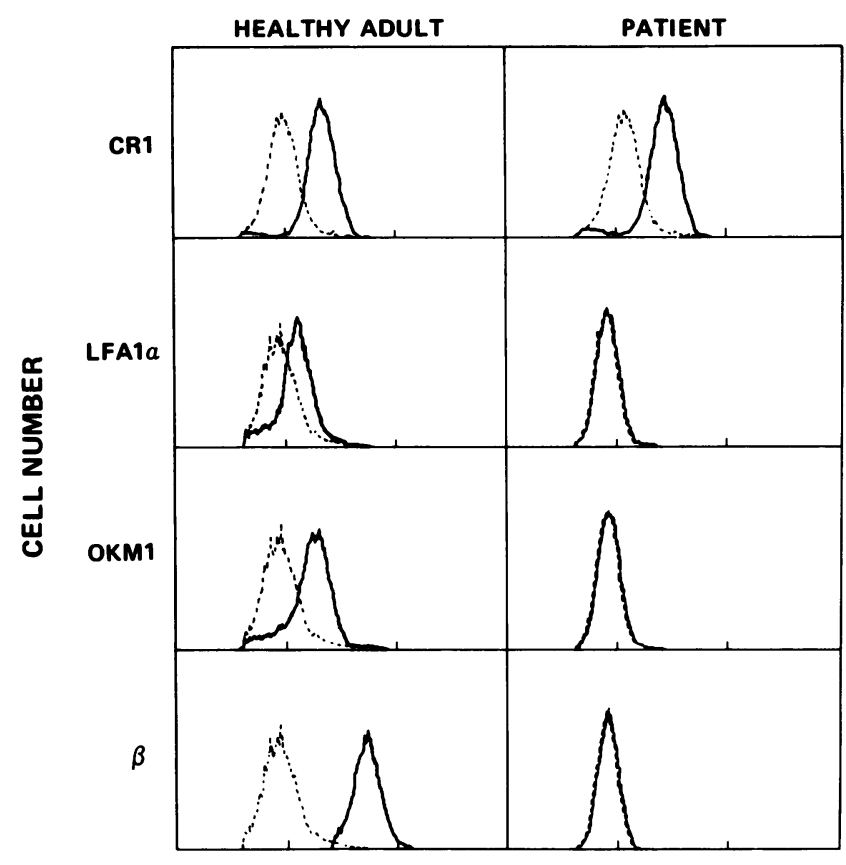

\section{RELATIVE FLUORESCENCE INTENSITY} (Log Scale)

Figure 3. Immunofluorescence flow cytometry. The surface expression of CR1, LFA1, and Mol/OKM1 on patient or control PMNs is shown. Cells were indirectly stained with a $F\left(a b^{\prime}\right)_{2}$ fragment of rabbit IgG anti-CR1 or MAbs directed at LFAl- $\alpha$, OKM1- $\alpha$ (and Mol), and their common subunit, and were then reacted with FITC-antimouse IgG or anti-goat $\mathbf{F}\left(\mathrm{ab}^{\prime}\right)_{2}(-)$. PMNs initially reacted with nonimmune ascites controls are also shown (-----). Paired histograms demonstrate relative fluorescence intensity $\left(\log _{10}\right)$ on the $X$ axis and cell number on the $\mathrm{Y}$ axis $\left(10^{4}\right.$ cells/histogram). Patient PMNs are totally deficient in surface OKM1/Mol- $\alpha$, LFAl- $\alpha$ and $\beta$ but express CR1 normally.

the use of radioimmunoassays employing ${ }^{125} \mathrm{I}-\mathrm{F}\left(\mathrm{ab}^{\prime}\right)_{2}$ MAbs (4, 43,48 ), which allow more precise quantitation of antigen binding sites per PMN, demonstrated that the patient's cells were totally lacking ( $<2 \%$ of normal) Mol and their common subunit (data not shown).

$P M N$ motility in vivo and in vitro. All motility studies were performed at times when the patient was clinically well and while receiving no medications. As shown with a Rebuck skin window technique (49), both PMN and mononuclear leukocyte mobilization in vivo was profoundly diminished (essentially no PMN or monocyte accumulation) despite marked peripheral blood leukocytosis. Both random and stimulated migration ("leading front" Boyden assay values) of patient PMNs were profoundly diminished $(P<0.001)$; values for paternal and maternal PMNs were normal (data not shown). Observations of the distributions of entire cell populations employing an Optomax Image Analyzer revealed mean cell migration (40 min) values in the patient of 7 (random) or $13 \mu \mathrm{m}$ (directed migration 
to f-Met-Leu-Phe) as compared with corresponding values of 27.2 and $47.3 \mu \mathrm{m}$, respectively, in healthy adult controls $(P<0.001)$.

Cell activation and shape change in suspension. Patient's PMNs demonstrated a normal capacity to undergo shape change in suspension in response to C5a or f-Met-Leu-Phe. Fig. 4 illustrates results for f-Met-Leu-Phe experiments. With respect to both C5a and f-Met-Leu-Phe, comparable threshold concentrations (C5a, $1.2 \mu \mathrm{g} / \mathrm{ml}$; f-Met-Leu-Phe, $0.1 \mathrm{nM}$ ) effected cell activation (membrane ruffling) of patient and control PMNs (24). At maximally effective concentrations (C5a; $4 \mu \mathrm{g} / \mathrm{ml}$, f-Met-Leu-Phe; $2 \mathrm{nM}$ ), the percent of patient PMNs demonstrating bipolar morphology was comparable with that of control cells (Fig. $4 A$ ). In kinetic experiments, patient PMNs demonstrated normal bipolar shape change at all time intervals between 20 and $60 \mathrm{~s}$ after exposure to $2 \mathrm{nM}$ f-Met-Leu-Phe (data not shown) and demonstrated normal uropod formation under all test conditions (Fig. $4 \mathrm{~B}$ ).

Specific binding of f-Met-Leu- ${ }^{3} \mathrm{H}$-Phe. Under conditions of saturation at $4^{\circ} \mathrm{C}$, the patient's cells demonstrated a normal number of specific binding sites for f-Met-Leu- ${ }^{3} \mathrm{H}-\mathrm{Phe}$ as compared with normal adult or maternal control values (7,000 binding sites/PMN for each donor). When binding $20 \mathrm{nM}$ f-MetLeu- ${ }^{3} \mathrm{H}-\mathrm{Phe}$ at $37^{\circ} \mathrm{C}(7)$, the patient's PMNs also demonstrated equivalent total and specific binding as compared with normal adult cells.

Assessments of PMN adherence. Results of studies employing serum-coated glass substrates are shown in Fig. 5. The technique employed evaluates cell attachment to test substrates in contrast with cell spreading or anchorage. Base-line adherence values of patient cells were diminished compared with adult, maternal,

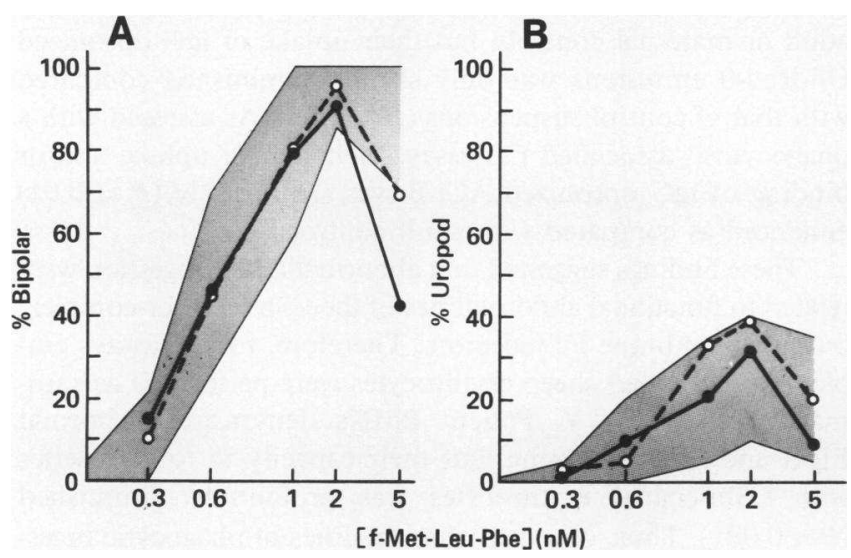

Figure 4. Activation and shape change of patient PMNs in response to f-Met-Leu-Phe. Patient, maternal, or control PMNs were stimulated in suspension with varying concentrations of f-Met-Leu-Phe for 5 min prior to fixation in $1.5 \%$ glutaraldehyde. Results shown are expressed as the mean $(n=2)$ of patient $(-\bullet-)$ or maternal (-.- 0 -.-) cells demonstrating $(A)$ bipolar morphology or $(B)$ uropods. Patient values are compared with a normal range (mean \pm 2 SD) of values for 75 healthy adults (shaded area). paternal, or age-matched control values $(P<0.005$ compared with all control suspensions). More striking abnormalities were apparent when modulation of patient cell adherence by CFs, PMA, or A23187 was attempted. Adult, maternal, or paternal PMNs exposed to f-Met-Leu-Phe (10 nM), C5a (40 $\mu \mathrm{g} / \mathrm{ml})$, or A23187 $(\mu \mathrm{M})$ demonstrated a normal enhancement of adherence, but essentially no enhancement was observed with patient PMNs $(P<0.001)$. Sequential stimulation of normal PMNs with increasing concentrations of CFs diminishes cell adherence as a result of a uniform redistribution of surface adhesion sites to cell uropods $(7,26)$. Healthy adult and maternal control suspensions studied under these conditions demonstrated expected low values (Fig. 5), but those for patient PMNs were comparable with base-line values $(P>0.05)$.

Adherence was also assessed with an ACLB binding assay (26). ACLB binding by patient cells following an exposure to f-Met-Leu-Phe, C5a, or A23187 was significantly $(P<0.001)$ less than that observed with healthy adult, maternal, or paternal control cells. The percentage of patient PMNs demonstrating no binding ( $58 \pm 6 \%$, f-Met-Leu-Phe; $52 \pm 6 \%$, C5a; $48 \pm 7 \%$, A23187) was significantly $(P<0.001)$ increased compared with values of $\leq 4 \pm 5 \%$ for all controls and test conditions. Of patient PMNs capable of binding ACLB, only 2.2 \pm 3.1 (f-Met-Leu-Phe), $3.1 \pm 1.0$ (C5a), or $14 \pm 5$ (A23187) beads/PMN were observed as compared with a range of values of 5-12, f-Met-Leu-Phe; 11-21, C5a; and 15->50, A23187 for control suspensions $(P<0.001)$.

In contrast, the distribution of ACLB binding sites of patient PMNs was essentially normal; they demonstrated a normal capacity to redistribute their "adhesion sites" to the cell uropod following sequential f-Met-Leu-Phe stimulation (patient, $55 \pm 14 \%$; healthy adult, $62 \pm 12 \%$; mother, $50 \pm 8 \%$; father, $63 \pm 11 \%$ ). Thus, impaired enhancement of patient cell adherence by chemotactic or secretory stimuli reflects a limited capacity to initiate new "adhesion sites" in response to these stimuli. A failure of sequential chemotactic stimuli to diminish their adherence would appear to reflect a diminished number of "adhesion sites" rather than an inability to laterally redistribute them to the cell uropod.

Aggregometry. Studies shown in Fig. 6 demonstrate a significantly $(P<0.001)$ diminished capacity of patient PMNs to aggregate when exposed to CFs, PMA, or A23187. As shown by immunofluorescence microscopy, a failure of the patient's cells to adhere to one another but not to control PMNs was confirmed by employing test mixtures of control PMNs and FITC-stained patient PMNs. Mean \pm SD values (in ZAP units) for CF-stimulated patient cells (f-Met-Leu-Phe, 28 \pm ; ZAP, 35 \pm 9$)$ were significantly $(P<0.001)$ diminished compared with values for maternal (f-Met-Leu-Phe, $84 \pm 12$; ZAP, 110 10 ), or healthy adult control (f-Met-Leu-Phe, 79 \pm 14 ; ZAP, 100 \pm 0 ) suspensions. In response to PMA $(10 \mu \mathrm{g} / \mathrm{ml})$ or A23187 $(\mu \mathrm{M})$, diminished aggregation by patient $(P<0.001)$ and maternal $(P<0.05)$ suspensions as compared with healthy adult control suspensions was also observed. 


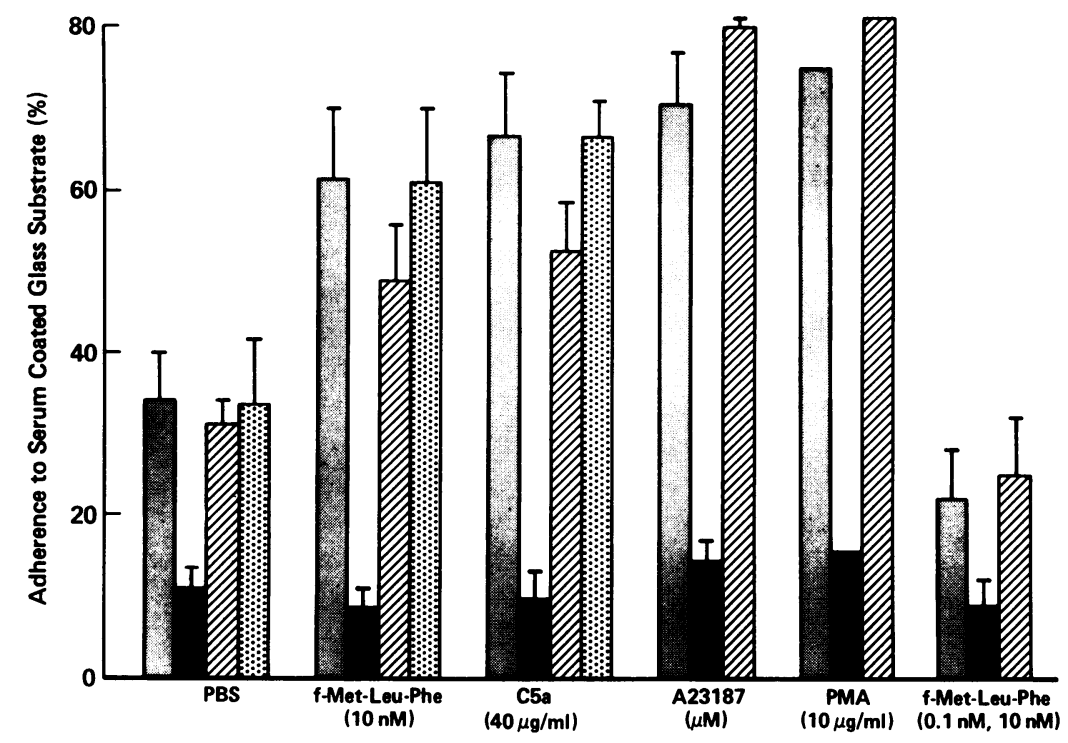

Figure 5. Adherence of patient or control PMNs to serum-coated glass substrates. Adherence of patient $(\square)$, maternal $(\varpi)$, paternal $(\bowtie)$, or healthy adult $(\varpi)$ PMNs to serum-coated glass substrates was tested under base-line conditions (PBS) and following their exposure to f-Met-Leu-Phe $(10 \mathrm{nM}), \mathrm{C} 5 \mathrm{a}(40 \mu \mathrm{g} / \mathrm{ml})$, A23187 $(\mu \mathrm{M})$, PMA $(10 \mu \mathrm{g} / \mathrm{ml})$, or sequential exposure to f-Met-Leu-Phe $(0.1 \mathrm{nM}, 10 \mathrm{nM})$. Values shown represent the mean \pm 1 SD of values determined from three to seven separate experiments.

Cell spreading (anchorage). Anchorage of patient cells to either glass or plastic substrates was severely diminished as compared with healthy adult, maternal, or age-matched controls (Table I). Furthermore, patient cells that were able to attach or anchor were easily detached by gentle rinsing with DPBS. Representative patient and control cells are illustrated by the scanning electron micrographs in Fig. 7.

Orientation on substrates in chemotactic gradients. The extent and accuracy of orientation by patient PMNs in gradients of f-Met-Leu-Phe or C5a are summarized in Table II. The percent of patient cells demonstrating the capacity to orient was markedly diminished; orientation at early, peak $(30 \mathrm{~min})$, or late time intervals was diminished $(P<0.001$ at all time intervals). However, the accuracy of orientation (percent directed into the positive gradient) by patient PMNs that were capable of orienting was comparable with control PMNs $(P>0.05)$.

An apparent discrepancy between findings of normal shape change by patient cells in suspension (Fig. 4) and impaired orientation while attached to surfaces was carefully evaluated with scanning electron micrographs of patient cells fixed while undergoing orientation in Zigmond chambers (Fig. 8). As shown, adherent patient cells were clearly activated (bipolar) in a plane perpendicular to the substrate after exposure to CFs (Fig. $8 \mathrm{D}$ ), but they were unable to initiate lateral or peripheral areas of attachment with the substrate (Fig. $8 \mathrm{E}$ ).

Degranulation. Studies of patient cell secretion in response to stimulation with CFs or PMA and "regurgitation" during phagocytosis of zymosan particles are summarized in Table III. With respect to CFs or PMA, patient cells demonstrated a normal capacity to release lysozyme, $\beta$-glucuronidase and lactoferrin, and a normal total cell protein content of each enzyme. $\mathrm{Cy}$ tochalasin B pretreatment effected significantly increased enzyme release, findings which are consistent with normal behavior of microfilament disassembly in the patient's cells. However, markedly diminished secretion by patient PMNs (not pretreated with cytochalasin B) was observed during phagocytic ingestion, suggesting a diminished kinetics of ingestion by patient cells rather than abnormal degranulation per se.

Studies of phagocytic ingestion. Results in Table IV demonstrate considerable heterogenity of phagocytosis by GP138deficient PMNs with respect to the test particle employed. Findings of diminished uptake by patient cells of radiolabeled staphylococcal organisms or zymosan confirmed previous findings for these test particles (6). Their uptake of Oil-Red-0-paraffin emulsions selectively opsonized with C3-derived ligands was also significantly $(P<0.01)$ diminished compared with healthy adult or maternal controls, but their uptake of IgG opsonized Oil-Red-0 emulsions was only slightly diminished compared with that of control suspensions $(P>0.05)$. As assessed with a phagocytosis-associated $C L$ assay, their rate of uptake and/or binding of IgG opsonized ACLB was significantly $(P<0.01)$ enhanced as compared with adult controls.

These findings suggested that abnormalities of ingestion were related to functional abnormalities of the $\mathrm{C} 3 \mathrm{~b}$ receptor complex, but not membrane Fc receptors. Therefore, rosette assays employing sensitizied sheep erythrocytes were performed as summarized in Table V. Patient PMNs demonstrated normal EIgG and EC3b rosetting, but their capacity to form rosettes with C3bi-coated erythrocytes was profoundly diminished $(P<0.001)$. Thus, observed abnormalities of phagocytic ingestion and immune adherence by the patient's PMNs are specifically related to the absence of surface OKM1/Mol and LFA1, despite normal expression of surface CR 1 .

Further studies confirmed that the patient cells demonstrated normal binding and ingestion via Fc receptors. As shown with ACLB opsonized with anti-HSA IgG, Fc receptors of both normal and patient PMNs pretreated with f-Met-Leu-Phe (1 nM) were distributed preferentially on cell lamellipodia and were 


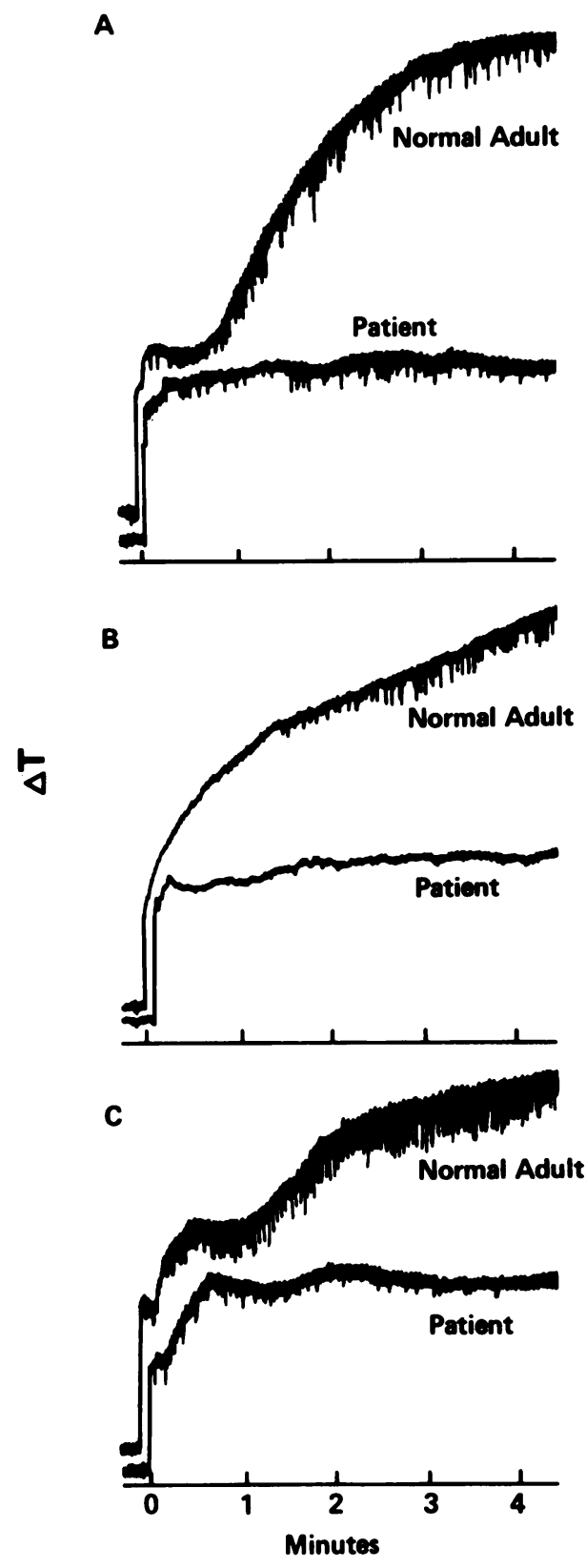

Figure 6. Aggregometry of patient or healthy adult PMNs. Representative aggregation tracings of patient or control PMNs (pretreated with cytochalasin $B$ ) in response to $(A)$ zymosan-activated serum, $(B)$ f-Met-Leu-Phe $(\mu \mathrm{M})$, or $(C)$ A23187 $(\mu \mathrm{M})$ are illustrated. As confirmed by phase-contrast microscopy, aggregates in patient suspensions were profoundly diminished or absent.

sequentially ingested and redistributed posterially (normally) toward the cell nucleus. As compared with control PMNs, normal binding distributions and normal kinetics of "Fc-facilitated" ingestion by patient cells were observed at 10,30, and $90 \mathrm{~s}$ after
Table I. Characteristics of Spreading by Patient or Control PMNs on Artificial Substrates

\begin{tabular}{|c|c|c|c|c|}
\hline \multirow[b]{2}{*}{ Test suspension } & \multicolumn{3}{|c|}{ Plastic $\left(21^{\circ} \mathrm{C}\right)$} & \multirow{2}{*}{$\begin{array}{l}\text { Glass } \\
\left(37^{\circ} \mathrm{C}, 15 \mathrm{~min}\right) \\
(n=4)\end{array}$} \\
\hline & $\begin{array}{l}5 \min \\
(n=2)\end{array}$ & $\begin{array}{l}15 \min \\
(n=2)\end{array}$ & $\begin{array}{l}45 \min \\
(n=5)\end{array}$ & \\
\hline Normal adult & $72^{*}$ & 87 & $95 \pm 7$ & $88 \pm 12$ \\
\hline Patient & 34 & 37 & $45 \pm 8 \ddagger$ & $25 \pm 29 \S$ \\
\hline Mother & 82 & 95 & $97 \pm 4$ & $88 \pm 16$ \\
\hline Age-matched control & 77 & 88 & $95 \pm 5$ & $82 \pm 20$ \\
\hline
\end{tabular}

* Percent of cells demonstrating spreading on substrate (mean \pm 1 $\mathrm{SD})$.

$\ddagger P<0.001$ compared with all control suspensions.

$\S P<0.05$ compared with all control suspensions.

exposure to anti-HSA-ACLB (data not shown). Finally, normal Fc receptor binding by GP138 deficient PMNs was shown by the additional findings that their impaired capacity to spread was normalized when exposed to HSA-anti HSA, but not HSAanti HSA $F\left(a b^{\prime}\right)_{2}$, coated glass substrates. Scanning electron micrographs shown in Fig. 9 demonstrate normal "Fc-facilitated" spreading by representative patient PMNs.

$A D C C$. The patient's PMNs were essentially nonreactive in ADCC at effector-to-target cell ratios from 100:1 to 30:1 (Table VI). The patient's mother had ADCC values similar to that of a normal adult control. To evaluate the role of cell adhesion with respect to this cytotoxic defect, an agarose single cell cytotoxicity assay was utilized. In this assay, 5 to $6 \%$ of maternal and adult control PMNs bound to target cells in the presence of antibody, in contrast to only $0.5 \%$ of the patient's cells $(P<0.001)$. So few target cells were bound by patient PMNs that calculation of the percent killed $(50 \pm 70 \%)$ was considered to be unreliable.

Characterization of cytoplasmic MTs. Quantitative or functional assessment of MTs of patients cells were performed employing tubulin IF (42). Because cells were easily detached from substrates during this procedure, cytocentrifugation was required to insure attachment to glass substrates. Both the mean number of MTs per cell (patient, 31.9 \pm 4.0 ; healthy adult, 34.8 \pm 4.5 ; $P>0.05)$ and the mean length of individual MTs of f-MetLeu-Phe (10 nM) stimulated patient PMNs (patient, 10.1 13.1 $\mu \mathrm{m}$; healthy adult, $9.7 \pm 2.4 \mu \mathrm{m} ; P>0.05$ ) were comparable with adult control cells and normal laboratory values (42). Normal MT function was evidenced by additional studies of lectin capping. Both the percentage of spontaneous concanavalin A caps (patient, $4 \%$; healthy adult, $4 \%$ ) as well as the percentage of cells with caps following colchicine or sequential f-Met-LeuPhe preincubation (patient: $83 \%$ [colchicine], 68\% [f-Met-LeuPhe]; healthy adult: $71 \%$ [colchicine], $76 \%$ [f-Met-Leu-Phe]) of patient PMN suspensions was comparable with healthy adult controls.

Oxidative metabolism. Unstimulated patient cells demonstrated minimal (normal) base-line CL activity. When stimulated 

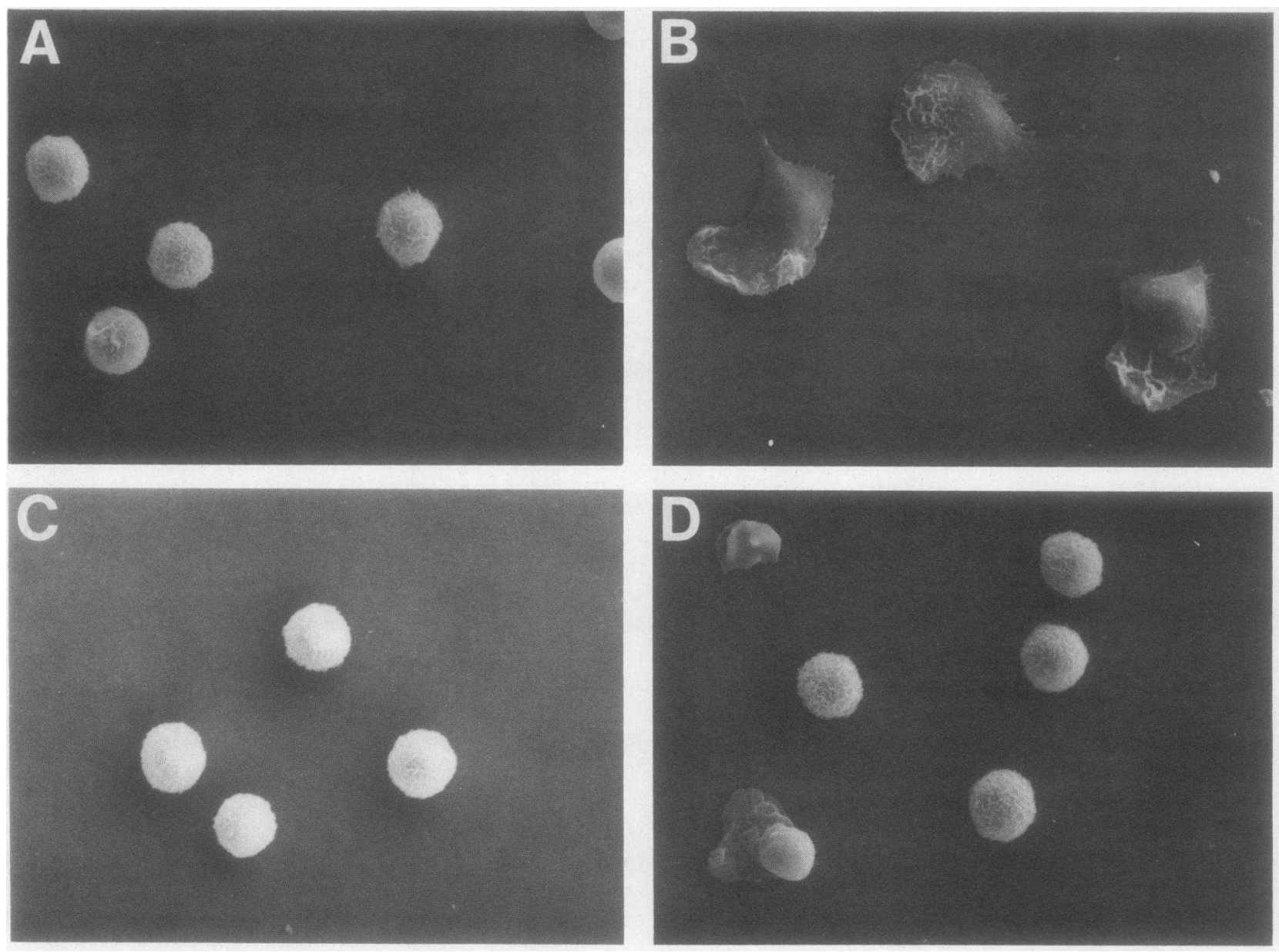

Figure 7. Spreading of patient or healthy adult PMNs on glass substrates. Representative scanning electron micrographs demonstrate the temporal response of attachment and spreading by healthy adult PMNs on glass substrates. $(A) 1 \mathrm{~min}$ after exposure to glass, adult

PMNs demonstrate no spreading; $(B)$ after 12 min, polarized spreading of essentially all cells has occurred. In contrast, patient PMNs $(C$, D) demonstrate an impaired capacity to spread.

with PMA or A23187 (data not shown), they demonstrated normal $\mathrm{O}_{2}^{-}$production and $\mathrm{CL}$ as compared with healthy adult, maternal, or age-matched control suspensions (PMA- ${ }_{2}^{-}$gen-

eration [ferricytochrome $\mathrm{C}$ reduction] [nanomoles per $5 \mathrm{~min}$ per $\left.10^{6} \mathrm{PMNs}\right]$; patient, $4.2 \pm 0.8$; mother, $5.1 \pm 1.2$; healthy adult, $5.2 \pm 0.9$ ), (PMA-CL evolution [CL integral $\times 10^{-4}-t=0-60$

Table II. Orientation by Patient or Healthy Adult PMNs Adhering to Albumin-Coated Glass

Substrates and Exposed to Gradients of f-Met-Leu-Phe or C5a

\begin{tabular}{rlclc}
\hline Cell donor & $\begin{array}{l}\text { Chemotactic gradient } \\
\text { conditions }\end{array}$ & $\begin{array}{l}\text { Percent of } \\
\text { PMNS orienting }\end{array}$ & $\begin{array}{l}\text { Percent of orienting PMNs directed } \\
\text { toward/away from gradient }\end{array}$ & $\begin{array}{l}\text { Percent of PMNs } \\
\text { accurately orienting }\end{array}$ \\
\hline $\begin{aligned} \text { Healthy } \\
\text { adult }\end{aligned}$ & f-Met-Leu-Phe & & & 57.0 \\
Patient & $(10 \mathrm{nM}), \mathrm{DPBS}$ & $67 \pm 11^{*}$ & $83 / 17$ & $6.5 \ddagger$ \\
Healthy & & $9 \pm 4 \ddagger$ & $74 / 26$ & \\
adult & C5a $(40 \mu \mathrm{g} / \mathrm{ml})$, & $57 \pm 12$ & $82 / 18$ \\
Patient & DPBS & $8 \pm 3 \ddagger$ & $75 / 25$ & $6.0 \ddagger$ \\
\hline
\end{tabular}

* Mean \pm 1 SD of values derived from evaluations of 250 cells in each of four separate experiments. $\ddagger P<0.001$ compared with healthy adult control. 

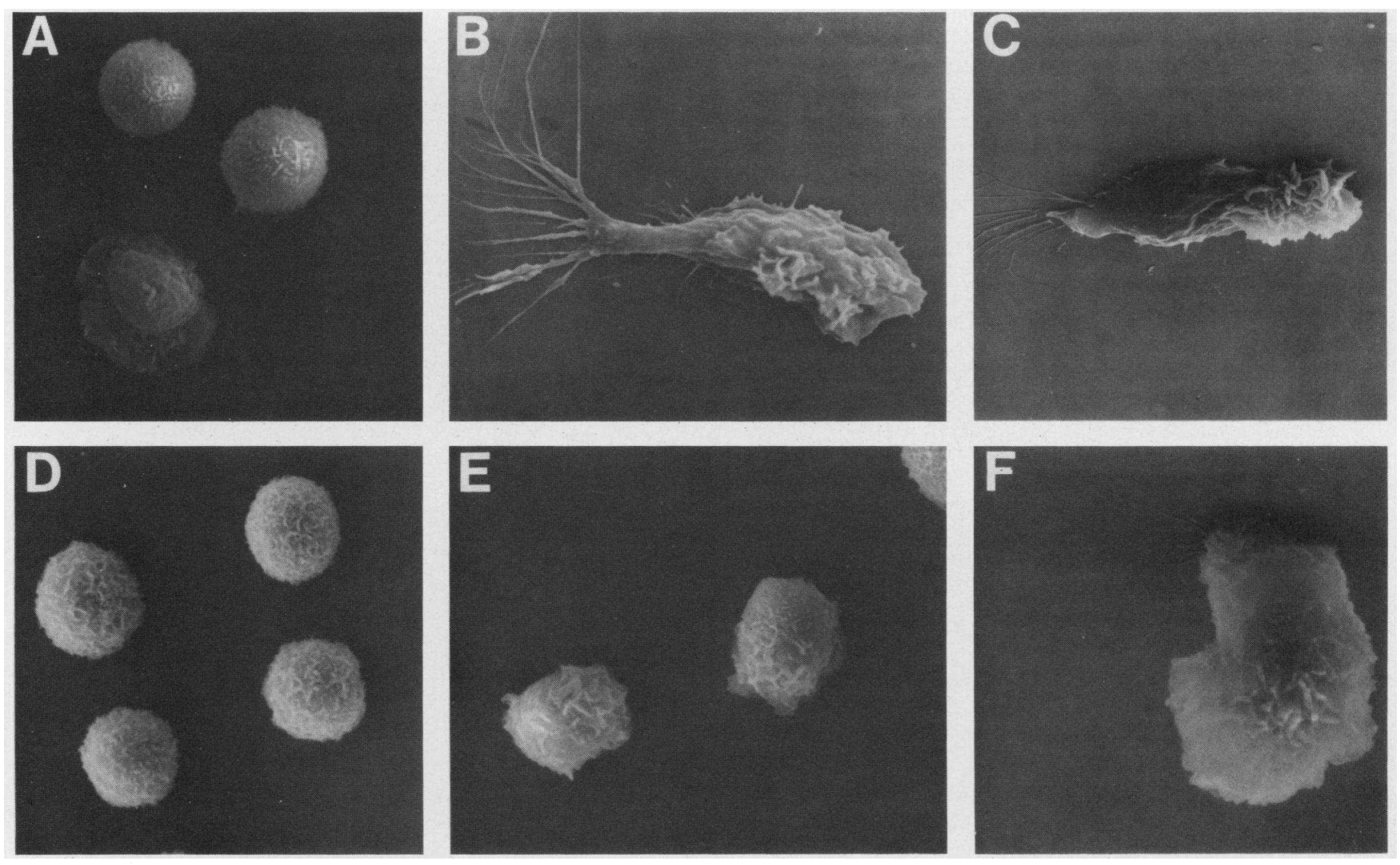

Figure 8. Orientation of patient or control PMNs in chemotactic gradients. Scanning electron micrographs show the sequence of $(A)$ cell activation (ruffling), $(B)$ and $(C)$ spreading and achievement of polarity (orientation) into the chemotactic gradient by healthy adult PMNs. The chemotactic gradient originates from the right side of the figure. Cells in $(A)$ and $(B)$ are photographed as visualized from above (or below) during orientation experiments. Frame $(C)$ shows a cell similar to that represented in $(B)$ as visualized in a plane perpendicular to the substrate to which the cell is attached. The same sequence is shown for patient PMNs $(D-F)$. Normal bipolar shape change of attached patient cells does occur $(F)$ but only in the plane perpendicular to the glass substrate $(A-E, \times 2,325 ; F, \times 4,300)$. min]; patient, 77.4 \pm 10.0 ; mother, 63.2 \pm 9.1 ; healthy adult, $59.7 \pm 12.1$ ). These findings indicate that diminished oxidative activity of patient PMNs during phagocytosis (Table IV) reflects abnormalities of cell-particle interactions rather than intrinsic abnormalities of the respiratory apparatus.

Membrane fluidity and cell surface charge. In further assessments of the biophysical properties of the patient's PMN membranes, the spin label 5-doxyl stearic acid and electron spin resonance spectroscopy were used to measure membrane fluidity. The order parameters $(S)$ of unstimulated control and patient PMNs at $37^{\circ} \mathrm{C}$ were equivalent $(S=0.637$ vs. 0.637 ). In addition, f-Met-Leu-Phe ( $10 \mathrm{nM})$ stimulated changes in membrane fluidity of patient PMNs were comparable with adult control PMNs (patient, $S=0.648 \pm 0.0014$; healthy adult, $S=0.649 \pm 0.0014$; $P>0.05)$.

The mean cell mobilities of healthy adult, patient, or maternal PMNs incubated with PBS were 2.72, 2.73, and 2.70, respectively. Similarly, the cell mobilities of PMNs stimulated with f-Met-Leu-Phe were essentially identical among these three donors.

\section{Discussion}

The critical role of cell adherence in allowing expression of normal PMN functions and the pathogenic importance of adhesive abnormalities in clinical disorders of PMN function have been increasingly recognized $(1-7,25,26,28,29,34,50-53)$. Molecular events contributing to adherence are incompletely understood, but studies employing time lapse photography or photomicrography have shown that PMNs adhere preferentially to vascular endothelium adjacent to a site of inflammation before their migration into tissues (54). This directed adherence is facilitated by the occupancy of membrane receptors by $\mathrm{C} 5 \mathrm{a}$ and other biproducts of inflammation which elicit a sequence of effects or mechanisms that enhance cellular adherence $(25,26$, $50,55-57)$. The identification in this case and in previous in- 
Table III. Degranulation by Patient or Control PMNs

\begin{tabular}{|c|c|c|c|c|c|c|c|}
\hline \multirow[b]{3}{*}{ Enzyme } & \multicolumn{7}{|c|}{ Release $(\overline{\mathrm{x}} \pm \mathrm{SD} \%$ of total) } \\
\hline & \multirow[b]{2}{*}{ PBS } & \multicolumn{2}{|l|}{ PMA } & \multicolumn{2}{|l|}{ f-Met-Leu-Phe } & \multicolumn{2}{|l|}{ Opsonized zymosan } \\
\hline & & No preincubation & Cytochalasin B & No preincubation & Cytochalasin B & No preincubation & Cytochalasin B \\
\hline \multicolumn{8}{|l|}{ Lysozyme } \\
\hline Patient & 2.0 & $9.5 \pm 5.1$ & $16.7 \pm 5.0$ & $3.5 \pm 0.7$ & $17.3 \pm 7.1$ & $7 \pm 2.0$ & $12 \pm 4.0$ \\
\hline Healthy adult & 2.1 & $7.5 \pm 6.5$ & $13.7 \pm 5.0$ & $5.3 \pm 0.3$ & $15.7 \pm 11$ & $20 \pm 3.1$ & $22 \pm 6.0$ \\
\hline Mother & 2.1 & $7.1 \pm 4.2$ & $16.0 \pm 3.0$ & $4.0 \pm 0.3$ & 28.0 & $19 \pm 2.0$ & $20 \pm 5.1$ \\
\hline \multicolumn{8}{|l|}{$\beta$-glucuronidase } \\
\hline Patient & 1.3 & 3.8 & $4.9 \pm 1.7$ & $2.8 \pm 2.3$ & $15.9 \pm 10.7$ & $2 \pm 2.1$ & $12 \pm 2.1$ \\
\hline Healthy adult & 2.0 & $4.8 \pm 1.1$ & $10.6 \pm 10.8$ & $3.2 \pm 1.3$ & $14.7 \pm 9.7$ & $10 \pm 3.1$ & $14 \pm 2.9$ \\
\hline Mother & 0.8 & $3.0 \pm 1.1$ & 8.0 & $1.6 \pm 2.1$ & 16.2 & 11 & $12 \pm 1.8$ \\
\hline \multicolumn{8}{|l|}{ Lactoferrin } \\
\hline Patient & 1.9 & 9.9 & 16.0 & 4.2 & 16.0 & $\mathrm{NT}^{*}$ & NT \\
\hline Healthy adult & 1.0 & 2.7 & 16.7 & 2.1 & 16.8 & NT & NT \\
\hline Mother & 1.2 & 3.0 & 17.0 & NT & NT & NT & NT \\
\hline \multicolumn{8}{|c|}{ Lactic dehydrogenase } \\
\hline Patient & $<1.0$ & $<1.0$ & $<1.0$ & $<1.0$ & $<1.0$ & 1.8 & NT \\
\hline Normal & $<1.0$ & $<1.0$ & $<1.0$ & $<1.0$ & $<1.0$ & $<1.0$ & NT \\
\hline Mother & $<1.0$ & $<1.0$ & $<1.0$ & $<1.0$ & $<1.0$ & - & NT \\
\hline
\end{tabular}

Results of total enzyme activity were as follows for patient cells, healthy adult control cells, and maternal cells, respectively (mean \pm 1 SD): $\beta$ glucuronidase ( $\left.\mathrm{nmol} / 5 \times 10^{6} \mathrm{PMNs}\right), 122 \pm 30,159 \pm 20,153 \pm 20$; lysozyme ( $\left.\mu \mathrm{g} / 5 \times 10^{6} \mathrm{PMNs}\right), 4.25 \pm 1.2,5.53 \pm 1.3,5.21 \pm 1.7$; lactic dehydrogenase (IU/ml $\left./ 5 \times 10^{5} \mathrm{PMNs}\right), 0.42 \pm 0.10,0.36 \pm 0.06,0.37 \pm 0.06$; lactoferrin $\left(\mu \mathrm{g} / 5 \times 10^{6} \mathrm{PMNs}\right), \sim 58.0$ for patient, healthy adult, and maternal PMNs. * Not tested.

vestigations of deficient glycoproteins in PMN homogenates, granule fractions, or on cell surfaces provides a molecular basis for understanding normal cellular adhesive properties as well as complex functional abnormalities observed in these disorders (2-5).

Studies in our patient emphasize that critical surface gly- coproteins are required for multiple adhesion-dependent PMN functions including motility, aggregation, orientation, cytotoxicity, phagocytosis, and leukocyte mobilization in vivo. Findings of impaired ADCC by GP138-deficient PMNs provide new evidence that this Fc receptor-mediated function appears to be also dependent upon an adhesive event unrelated to immu-

Table IV. Phagocytosis by Patient or Healthy Adult PMNs

\begin{tabular}{|c|c|c|c|c|c|}
\hline Cell donor & $\begin{array}{l}\text { Paraffin oil } \\
\text { emulsion }\left(l_{g G}\right)^{*} \\
(n=2)\end{array}$ & $\begin{array}{l}\text { Paraffin oil } \\
\text { emulsion }(\mathrm{C} 3 \mathrm{~b})^{*} \\
(n=3)\end{array}$ & $\begin{array}{l}\text { Radiolabeled } \\
\text { S. aureus 502A } \neq \\
(n=3)\end{array}$ & $\begin{array}{l}\text { Zymosan§ } \\
(n=3)\end{array}$ & $\begin{array}{l}\text { Latex beads } \\
(\mathrm{Ig}) \S \\
(n=3)\end{array}$ \\
\hline Patient & $1.1 / 1.95$ & $2.35^{\|} / 3.70^{\|}$ & $19 \pm 4^{* *}$ & $3 \pm 1^{* *}$ & $20 \pm 4.8+\dagger$ \\
\hline \multicolumn{6}{|l|}{ Healthy } \\
\hline adult & $1.2 / 2.31$ & $3.95 / 6.95$ & $39 \pm 5$ & $20 \pm 6$ & $13 \pm 3.0$ \\
\hline Mother & $0.7 / 1.80$ & $3.80 / 5.85$ & $\mathrm{NT}^{* *}$ & NT & NT \\
\hline
\end{tabular}

* Dionylphthalate uptake ( $\mu \mathrm{g} / 10^{6} \mathrm{PMNs}$ in $5 / 15 \mathrm{~min}$ ); values shown represent the mean of two experiments. $¥$ Percent uptake at 6 min; values shown represent the mean \pm 1 SD of $n$ experiments. §Slope of CL evolution $\left(\mathrm{CPM}^{2} \times 10^{-5}\right)$; values shown represent the mean \pm 1 SD of $n$ experiments. "Significantly $(P<0.001)$ diminished compared with healthy adult and maternal controls. I Significantly $(P<0.001)$ diminished compared with healthy adult control. ** Significantly $(P<0.05)$ increased compared with healthy adult control. $¥$ NT, not tested. 
Table V. Percent of PMNs Rosetting with IgG, C3b, or C3bi-coated Sheep Erythrocytes

\begin{tabular}{|c|c|c|c|c|c|c|}
\hline & \multirow[b]{2}{*}{ ELgG } & \multirow[b]{2}{*}{$\mathrm{EC} 3 \mathrm{~b}$} & \multicolumn{4}{|l|}{ EC3bi } \\
\hline & & & Buffer & $\begin{array}{l}\text { Buffer } \\
+F\left(a b^{\prime}\right)_{2} \text { anti-CR } 1\end{array}$ & $\begin{array}{l}\text { Buffer } \\
+\mathrm{F}\left(\mathrm{ab}^{\prime}\right)_{2} \text { anti-Mol }\end{array}$ & $\begin{array}{l}\text { Buffer + Anti-CRI } \\
+ \text { Anti-Mol }\end{array}$ \\
\hline \multicolumn{7}{|c|}{ PMN suspension } \\
\hline Patient & $63,76^{*}$ & $61,67 \ddagger$ & 9,10 & 0,2 & 0,13 & 0,1 \\
\hline Control & 65,87 & 68,84 & 65,74 & 59,62 & 15,15 & 1,3 \\
\hline
\end{tabular}

* Values are the means of two separate determinations performed on two different test dates. $¥$ Anti-CR 1 was used at a concentration that produced $>95 \%$ inhibition of EC $3 \mathrm{~b}$ rosetting with PMN.

noglobulin-PMN Fc receptor linkage. Additionally, this patient represents the first reported clinical example of pathologic ADCC due to impaired PMN target cell binding. Impaired phagocytosis of IgG-coated $\left[{ }^{14} \mathrm{C}\right] S$. aureus suggests a similar role for this glycoprotein complex in this function independent of the Fc receptor. The additional findings of normal shape change by GP138-deficient PMNs in suspension in contrast with their impaired orientation when attached to surfaces emphasize critical adhesive requirements for the latter function and indicate important functional differences between bipolar shape change by PMNs in suspension and their achievement of polarity while attached to surfaces.

Functional analyses of our patient's PMNs indicated that GP138 is not topographically and/or functionally related to Fc, C5a, f-Met-Leu-Phe, or PMA receptors, but did suggest a relationship to receptors which react with C3-derived ligands. Studies employing relevant MAbs confirmed that the patient's PMNs (and monocytes) were totally deficient in Mol (equivalent to OKM1), a surface glycoprotein containing a nonconvalentlylinked $\alpha$-subunit (155 kD) and $\beta$-subunit $(94 \mathrm{kD})(47,58)$. The $155 \mathrm{kD}$ subunit is closely associated or identical with the $\mathrm{C} 3 \mathrm{bi}$ receptor (CR3) of human myeloid cells (47). The $\beta$-molecule is shared by two other structurally similar and functionally related surface glycoproteins, including LFA1 and P150,95 $(5,49)$. As shown by IF flow cytometry and immunoprecipitation experiments, our patient's cells also totally lacked LFA1. Moderately diminished amounts of OKM1 and LFA1 were also detected in maternal PMNs.

Abnormalities of PMN adherence-dependent functions observed in this case are consistent with previously recognized functional activities of human Mol/OKM1 and LFA1. Both molecules act to strengthen adhesions between effector cells and target cells, and in both cases, the participation of additional cell surface molecules is required for optimal functional activity (47, 58-61). LFA1 acts together with the antigen receptor in cytotoxic $T$ lymphocyte-mediated killing $(47,58)$, and Mol

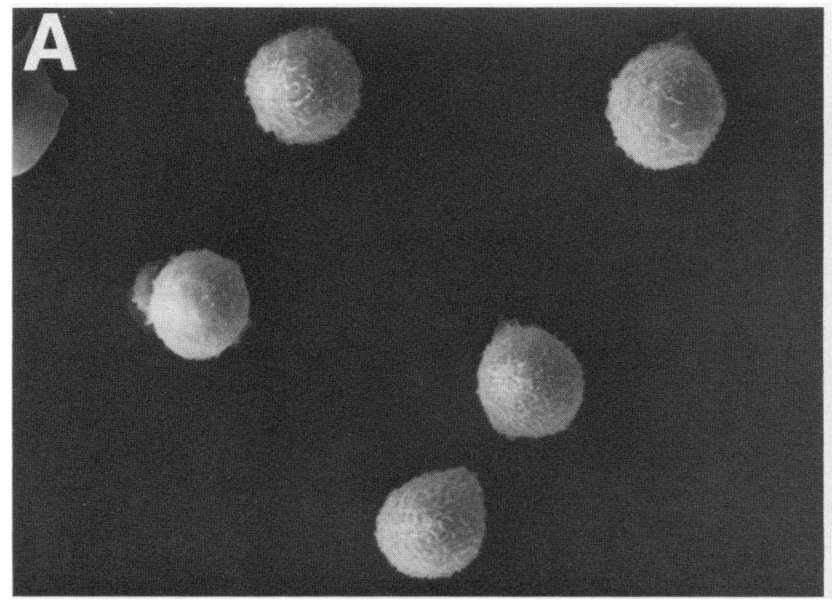

Figure 9. Spreading of patient or control PMNs facilitated by Fc receptors. Glass substrates were pretreated with 5\% HSA for 2 min, after which they were washed or reacted with rabbit anti-HSA for 30 min at $21^{\circ} \mathrm{C}$. PMNs were then allowed to spread on these substrates

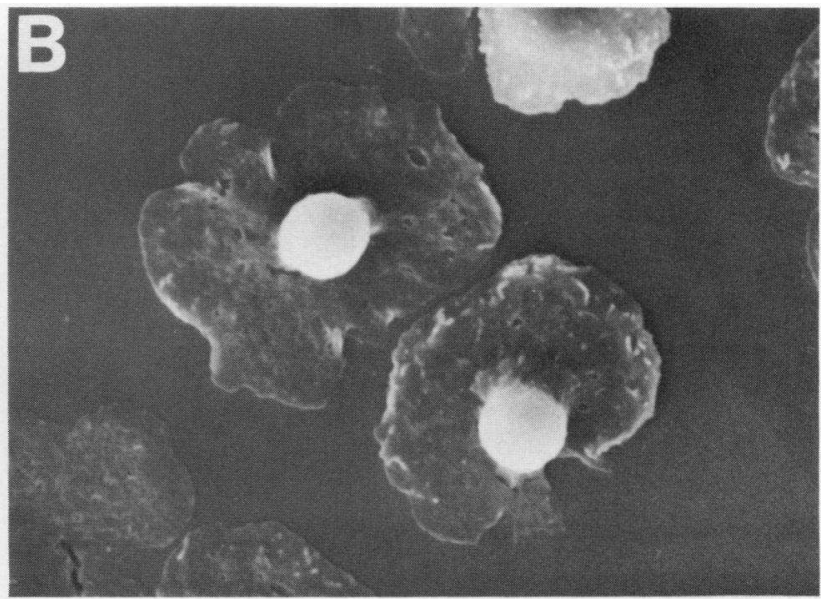

for $12 \mathrm{~min}$. These scanning electron micrographs demonstrate $(A)$ impaired spreading by patient PMNs on HSA-treated glass substrates, and $(B)$ normal spreading on HSA-anti HSA-coated glass. 
Table VI. PMN Antibody-dependent Cellular

Cytotoxicity and Target Cell Binding

\begin{tabular}{llrl}
\hline $\begin{array}{l}\text { Effector-to-target } \\
\text { cell ratio* }\end{array}$ & Patient & \multicolumn{1}{l}{ Mother } & Healthy adult control \\
\hline $100: 1$ & $2.0 \pm 2.8$ & $14.9 \pm 2.5$ & $19.9 \pm 0.9$ \\
$60: 1$ & $1.4 \pm 1.5$ & $13.8 \pm 2.9$ & $15.3 \pm 2.8$ \\
$30: 1$ & $2.7 \pm 3.8$ & $10.5 \pm 3.2$ & $12.8 \pm 5.8$ \\
$\begin{array}{l}\text { Percent target binding } \\
\text { Percent killing of }\end{array}$ & $0.5 \pm 0$ & $6.3 \pm 1.8$ & $5.2 \pm 0.9$ \\
$\quad$ bound target cells§ & $50 \pm 70.7$ & $65.0 \pm 7.1$ & $38.5 \pm 7.7$
\end{tabular}

* Results are the mean \pm SD of percent ADCC in two separate experiments using a radiolabeled target cell $\mathrm{Cr}$ release cytotoxicity assay at three effector-to-target cell ratios.

‡ Results are the mean \pm SD of two separate experiments which expressed target cell binding in a single cell agarose assay in the presence of anti-HSV antibody (final concentration $=1: 25$ ).

$\S$ Results are the mean \pm SD of the percent target cells killed of those bound to PMNs in the single cell agarose assay.

(CR3) acts synergistically with the Fc receptor to stimulate phagocytosis by macrophages and granulocytes (59-61) and killing by antibody-dependent cytotoxic effectors (60). In addition, both CTL-target cell adherence (61) and adherence through the CR3 $(62,63)$ are dependent on divalent cations. In contrast, adherence mediated by $\mathrm{CR} 1$ and Fc receptors (both normal in our patient) are divalent cation-independent (64).

Precise comparisons between our patient and those in previous studies have been limited due to the convention of reporting estimates of the molecular weight of PMN glycoproteins as determined by SDS-PAGE (2-5). Depending on the conditions of SDS-PAGE in this study, estimates of the molecular weight of the deficient glycoprotein ranged from 138 to $229 \mathrm{kD}$. SDS does not bind to proteins with large sugar content as efficiently as to other proteins, thus accounting for an anomolous behavior of glycoproteins in SDS-PAGE systems $(65,66)$. Considering these limitations, the use of specific MAb to surface antigens will be required to compare patients with leukocyte glycoprotein deficiency syndromes.

The collaborative use of MAbs to Mol and LFA1 has confirmed that our patient (GP138 deficiency) represents an example of an identical or very similar disorder (GP150 deficiency) previously described by Arnaout et al. $(4,5)$. Differences between the functional capabilities of GP150-deficient as compared with GP138-deficient PMNs may be explained by quantitative differences of Mol deficiency among these two patients. Scatchard analyses of ${ }^{125} \mathrm{I}-\mathrm{F}\left(\mathrm{ab}^{\prime}\right)_{2}$ anti-Mol binding data revealed that the previously reported male patient $(4,5)$ had $7,000 \pm 3,000$ Mol sites/cell as compared with 0 sites/cell in our patient, and $65,000 \pm 7,000$ sites/cell for normal controls. Studies in another male patient with GP138 deficiency indicate diminished $(\simeq 10 \%$ of normal) but not totally deficient PMN OKM1 (67). Our patients and those previously described in detail by Crowley et al. (2), Bowen et al. (3), Arnaout et al. (4, 5), and Beatty et al. (68) probably represent variants of a similar group of disorders characterized by abnormalities of PMN membrane glycoproteins. Other male and female infants with delayed umbilical cord separation and/or recurrent severe infections may represent additional examples of Mo1/LFAl deficiency syndrome (68-72).

Abnormalities of PMN adherence and associated deficits of chemotaxis have been previously recognized in other clinicopathologic models demonstrating impaired inflammation and enhanced susceptibility to microbial invasion $(2-7,23,28,50-$ 54). Abnormal neutrophil adherence, aggregation, and chemotaxis in vitro associated with a heritable deficiency of specific granule lactoferrin has been well described in two patients (29, 51). In one case, the incubation of purified neutrophil lactoferrin with patient cells permitted them to adhere normally, suggesting that diminished lactoferrin secretion was responsible for complex defects of membrane associated cell function, including abnormalities of cell surface charge. Our patient's cells demonstrated normal surface charge, normal specific granule morphology (transmission EM), and normal secretion of lactoferrin in response to CFs or secretagogues. The extent of lactoferrin release by Mo1/LFA1-deficient PMNs in vivo while adhering to endothelial cells (margination) or during inflammation remains to be determined.

Elevated adherence associated with abnormalities of neutrophil motility and cyclic nucleotide metabolism was reported in a female patient with recurrent soft tissue infections (52). Excessive MT assembly was observed in that patient's cells in contrast with our findings. Mol/LFA1 does not appear to be required for polymerization or depolymerization of MTs per se. However, since adherence itself promotes MT assembly in normal PMNs, deficiency of Mo1/LFA1 may indirectly impair MT function (42).

\section{Acknowledgments}

The authors acknowledge the cooperation of the patient and her family in the facilitation of these investigations, and the fine secretarial support of Jo Ann Guerinot and Marie Mason throughout the many revisions of this manuscript. We also thank Dr. Ralph D. Feigin for his critical review of the manuscript, useful suggestions, and continuing support. We also acknowledge the technical support of many other individuals who made contributions to the collaborating laboratories and institutions participating in these studies.

This research was supported in part by grants from the National Institutes of Health Nos. AI 19031, AI 20226, AI 16810, and CA31798, Biomedical Research Support Grants to Baylor College of Medicine (No. RR 05425-21) and the University of Texas Medical Branch at Galveston (Nos. RR 05427 and RR 07205) from the National Institutes of Health, the U. S. Department of Agriculture/Agricultural Research Service Children's Nutrition and Research Center, Baylor College of Medicine and Texas Children's Hospital, and the American Heart Association. Dr. Anderson is a recipient of a Research Career Development 
Award from the National Institutes of Allergy and Infectious Diseases (1 K04 AI/AM 00501-01). Dr. Arnaout and Dr. Boxer were Established Investigators of the American Heart Association while this work was performed.

\section{References}

1. Johnston, R. B. 1982. Defects of neutrophil function. N. Engl. J. Med. 307:434-436.

2. Crowley, C. A., J. T. Curnutte, R. E. Rosin, J. Andre-Schwartz, J. I. Gallin, J. I. Klempner, R. Snyderman, F. S. Southwick, T. P. Stossel, and B. M. Babior. 1980. An inherited abnormality of neutrophil adhesion: its genetic transmission and its association with a missing protein. $N$. Engl. J. Med. 302:1163-1168.

3. Bowen, T. J., H. D. Ochs, L. C. Altman, T. H. Price, D. E. VanEpps, D. L. Brautigan, R. E. Rosin, W. D. Perkins, B. M. Babior, S. J. Klebanoff, and R. J. Wedgwood. 1982. Severe recurrent bacterial infections associated with defective adherence and chemotaxis in two patients with neutrophils deficient in a cell-associated glycoprotein. $J$. Pediatr. 101:932-940.

4. Arnaout, M. A., J. Pitt, H. J. Cohen, J. Melamed, F. S. Rosen, and H. R. Colten. 1982. Deficiency of a granulocyte-membrane glycoprotein (GP150) in a boy with recurrent bacterial infections. $N$. Engl. J. Med. 306:693-699.

5. Dana, N., R. F. Todd III, J. Pitt, T. A. Springer, and M. A. Arnaout. Deficiency of a surface membrane glycoprotein (Mol) in man. J. Clin. Invest. 73:153-159.

6. Abramson, J. S., E. L. Mills, M. K. Sawyer, W. R. Regelmann J. D. Nelson, and P. G. Quie. 1981. Recurrent infections and delayed separation of the umbilical cord in an infant with abnormal phagocytic cell locomotion and oxidative response during partial phagocytosis. $J$. Pediatr. 99:887-894.

7. Anderson, D. C., B. J. Hughes, and C. W. Smith. 1981. Abnormal mobility of neonatal polymorphonuclear leukocytes. Relationship to impaired redistribution of surface adhesion sites by chemotactic factor or colchicine. J. Clin. Invest. 68:863-874.

8. Gallin, J. I., and A. A. Rosenthal. 1974. The regulatory role of divalent cations in human granulocyte chemotaxis. Evidence for an association between calcium exchanges and microtubule assembly. $J$. Cell Biol. 62:594-609.

9. Andersson, L. C., and C. G. Gahmberg. 1978. Surface glycoproteins of human white blood cells. Analysis by surface labeling. Blood. 52:5767.

10. Oseas, R. S., H. H. Yang, R. L. Baehner, and L. A. Boxer. 1981. Lactoferrin: a promoter of polymorphonuclear leukocyte adhesiveness. Blood. 57:939-945.

11. Brinkley, B. R., G. M. Fuller, and D. P. Highfield. 1975. Cytoplasmic microtubules in normal and transformed cells in culture: analysis by tubulin antibody immunofluorescence. Proc. Natl. Acad. Sci. USA. 73:4981-4985.

12. Todd, R. F., III, and S. F. Schlossman. 1982. Differentiation antigens on human monocytes and macrophages defined by monoclonal antibodies. In Mononuclear Phagocytic Biology. A. Volkman, editor. Marcel-Dekker, NY. In press.

13. Sanchez-Madrid, F., A. M. Krensky, C. F. Ware, E. Robbins, J. L. Strominger, S. J. Burakoff, and T. A. Springer. 1982. Three distinct antigens associated with human T lymphocyte-mediated cytolysis: LFA1, LFA, and LFA-3. Proc. Natl. Acad. Sci. USA. 79:7489-7493.
14. Stanworth, D. R., and M. W. Turner. 1978. Immunochemical analysis. In Handbook of Experimental Immunology. D. M. Weir, editor. Blackwell, Oxford. 25-34.

15. Fearon, D. T. 1980. Identification of the membrane glycoprotein that is the $\mathrm{C} 3 \mathrm{~b}$ receptor of the human erythrocyte, polymorphonuclear leukocyte, B lymphocytes, and monocyte. J. Exp. Med. 152:20-30.

16. Laemmli, U. K. 1970. Cleavage of structural proteins during the assembly of the head of bacteriophage T4. Nature (Lond.). 227:680685.

17. Dubray, G., and G. Bezara. 1982. A highly sensitive periodic acid-silver stain for 1,2-diol groups of glycoproteins and polysaccharides in polyacrylamide gels. Anal. Biochem. 119:325-329.

18. Gahmberg, C. G. 1978. Tritium labeling of cell-surface glycoproteins and glycolipids using galactose oxidase. Methods Enzymol. 50:204-206.

19. Gahmberg, C. G., and S.-I. Hakomori. 1973. External labeling of cell surface galactose and galactosamine in glycolipid and glycoprotein of human erythrocytes. J. Biol. Chem. 248:4311-4317.

20. Hobson, G. E. 1976. A procedure to increase the sensitivity of staining by Coomassie brilliant blue G250-perchloric acid solution. Anal. Biochem. 250:634-636.

21. Todd, R. F., III, L. M. Nadler, and S. F. Schlossman. 1981. Antigens on human monocytes identified by monoclonal antibodies. $J$. Immunol. 126:1435-1442.

22. Fearon, D. T., and L. A. Collins. 1983. Increased expression of C3b receptor on PMN leukocytes induced by chemotactic factors and by purification procedures. J. Immunol. 130:370-379.

23. Zigmond, S. H., and J. G. Hirsch. 1973. Leukocyte locomotion and chemotaxis. New in vitro method for evaluation and demonstration of a cell derived chemotactic factor. J. Exp. Med. 137:387-418.

24. Maderazo, E. G., and C. L. Weronick. 1978. Micropore filter assay of human granulocyte locomotion: problems and solutions. Clin. Immunol. Immunopathol. 11:196-211.

25. Smith, C. W., J. C. Hollers, R. A. Patrick, and C. Hassett. 1979. Motility and adhesiveness in human neutrophils. Effects of chemotactic factors. J. Clin. Invest. 63:221-229.

26. Smith, C. W., and J. C. Hollers. 1980. Motility and adhesiveness in human neutrophils. Redistribution of chemotactic factor-induced adhesion sites. J. Clin. Invest. 65:804-812.

27. Hammerschmidt, P. E., T. K. Bowers, C. J. Kammi-Kepfe, H. S. Jacob, and P. R. Craddock. 1980. Granulocyte aggregometry: a sensitive technique for the detection of C5a and complement activation. Blood. 55:898-902.

28. Zigmond, S. H. 1977. Ability of polymorphonuclear leukocytes to orient in gradients of chemotactic factors. J. Cell Biol. 75:606-616.

29. Boxer, L. A., T. D. Coates, R. A. Haak, J. B. Wolach, S. Hoffstein, and R. L. Baehner. 1982. Lactoferrin deficiency associated with altered granulocyte function. N. Engl. J. Med. 307:409-416.

30. Osserman, E. F., and D. F. Lawler. 1966. Serum and urine lysozyme (muraminidase) in monocyte and monomyeloleukocytic leukemia. J. Exp. Med. 124:921-947.

31. Lombardo, A., L. Caimi, S. Marchesini, G. Gai, and G. Tehamanti. 1980. Enzymes of lysosomal origin in human plasma and serum: assay conditions and parameter influencing the assay. Clin. Chem. Acta. 108:337-346.

32. Wacker, W. E. C., D. N. Ulmer, and B. L. Vallee. 1956. Metalloenzymes and myocardial infarction. N. Engl. J. Med. 225:449-457.

33. Babior, B. M., R. S. Kipnes, and J. T. Curnuette. 1973. Biological 
defense mechanisms. The production by leukocytes of superoxide, a potential bactericidal agent. J. Clin. Invest. 52:741-744.

34. Anderson, D. C., M. Mace, R. R. Martin, and C. W. Smith. 1981. Recurrent infection in glycogenosis type $1 \mathrm{~b}$ : abnormal neutrophil mobility related to impaired redistribution of adhesion sites. J. Infect. Dis. 143:447-459.

35. Stossel, T. P. 1973. Evaluation of opsonic and leukocyte function with a spectrophotometer test in patients with infection and with phagocytic disorders. Blood. 42:121-128.

36. Shurin, S. B., and T. P. Stossel. 1978. Complement (C3)-activated phagocytosis by lung macrophages. J. Immunol. 120:1305-1312.

37. Peterson, P. K., B. J. Wilkinson, Y. Kim, D. Schmeling, and P. G. Quie. 1978. Influence of encapsulation on staphylococcal opsonization and phagocytosis by polymorphonuclear leukocytes. Infect. Immun. 19:943-953.

38. Ross, G. D., S. L. Newman, J. D. Lambris, J. E. Devery-Pocius, J. A. Kain, and P. J. Lachmann. 1983. Generation of three different fragments of bound $\mathrm{C} 3$ with purified factor 1 or serum. II. Location of binding sites in the $\mathrm{C} 3$ fragments for factor $\mathrm{B}$ and $\mathrm{H}$, complement receptors, and bovine conglutinin. J. Exp. Med. 158:334-352.

39. Kohl, S., S. E. Starr, J. M. Oleske, S. L. Shore, R. B. Ashman, and A. J. Nahmias. 1977. Human monocyte-macrophage mediated antibody-dependent cytotoxicity to herpes simplex virus-infected cells. $J$. Immunol. 118:729-735.

40. Kohl, S., J. P. Frazier, L. K. Pickering, and L. S. Loo. 1981. Normal function of neonatal polymorphonuclear leukocytes in antibodydependent cellular cytotoxicity to herpes simplex virus-infected cells. $J$. Pediatr. 98:783-785.

41. Silva, A., B. Bonavida, and S. Targan. 1980. Mode of action of interferon-mediated modulation of natural killer cytotoxicity activity: recruitment of pre-NK cells and enhanced kinetics of lysis. J. Immunol. 125:479-484.

42. Anderson, D. C., L. J. Wibel, B. J. Hughes, C. W. Smith, and B. R. Brinkley. 1982. Cytoplasmic microtubules in polymorphonuclear leukocytes: effects of chemotactic stimulation and colchicine. Cell. 31:719-729.

43. Oliver, J. M. 1976. Concanavalin A cap formation on human polymorphonuclear leukocytes induced by R7934, a new antitumor drug that interferes with microbial assembly. J. Reticuloendothel. Soc. 19:389-395.

44. Haak, R. A., L. M. Ingerham, and R. L. Baehner. 1979. Membrane fluidity in human and mouse Chediak-Higashi leukocytes. J. Clin. Invest. 64:138-144.

45. Bass, D. A., W. H. Boxer, J. C. Lewis, P. Szejda, L. R. DeChatelet, and C. E. McCall. 1980. Comparison of human eosinophils from normals and patients with eosinophilia. J. Clin. Invest. 66:1265-1273.

46. Fenner, C., R. R. Traut, D. T. Mason, and J. Wikman-Coffelt. 1975. Quantitation of Coomassie blue stained proteins in polyacrylamide gels based on analyses of eluted dye. Anal. Biochem. 63:595-602.

47. Arnaout, M. A., R. F. Todd III, N. Dana, J. Melamed, S. F. Schlossman, and H. R. Colten. 1983. Inhibition of phagocytosis of complement $\mathrm{C} 3$ or IgG-coated particles and of $\mathrm{C} 3 \mathrm{bi}$ binding by monoclonal antibodies to a monocyte-granulocyte membrane glycoprotein (Mol). J. Clin. Invest. 72:171-179.

48. Sanchez-Madrid, F., J. A. Nagy, E. Robbins, P. Simon, and T. A. Springer 1983. A human leukocyte differentiation antigen family with distinct $\alpha$-subunits and a common $\beta$-subunit: the lymphocytefunction associated antigen (LFA-1), the C3bi complement receptor
(OKM1/Mac-1), and the p150,95 molecule. J. Exp. Med. 158:17851803.

49. Rebuck, J. W., and J. H. Crowley. 1955. A method of studying leukocytic functions in vivo. Ann. NY. Acad. Sci. 59:757-805.

50. Gallin, J. I. 1981. Abnormal phagocytic chemotaxis: pathophysiology, clinical manifestations and management of patients. Rev. Infect. Dis. 3:1196-1220.

51. Gallin, J. I., M. D. Fletcher, B. E. Seligman, S. Hoffstein, K. Ochrs, and N. Mennessa. 1982. Human neutrophil-specific granules deficiency: a method to assess the role of neutrophil-specific granules in the evolution of the inflammatory response. Blood. 59:1317-1329.

52. Gallin, J. I., H. L. Malech, D. G. Wright, J. Whisant, and C. H. Kirkpatrick. 1978. Recurrent severe infections in a child with abnormal leukocyte function: possible relationship to increased microtubular assembly. Blood. 51:919.

53. Mease, A. D., G. W. Fischer, K. W. Hunter, and F. B. Reymann. 1980. Decreased phytohemmaglutinin-induced aggregation and C5ainduced chemotaxis of human newborn neutrophils. Pediatr. Res. 14:142-146.

54. Atherton, A., and G. V. R. Bern. 1972. Quantitative investigations of the adhesiveness of circulating polymorphonuclear leukocytes to blood vessel walls. J. Physiol. 222:447-474.

55. Hoffstein, S. T., R. S. Friedman, and G. Weissmann. 1982. Degranulation, membrane addition, and shape change during chemotactic factor-induced aggregation of human neutrophils. J. Clin. Invest. 65:298-306.

56. Gallin, J. I. 1980. Degranulating stimuli decrease the negative surface charge and increase the adhesiveness of human neutrophils. $J$. Clin. Invest. 65:298-306.

57. Hoover, R. L., R. T. Briggs, and M. J. Karnovsky. 1978. The adhesive interaction between polymorphonuclear leukocytes and endothelial cells in vitro. Cell. 14:423-428.

58. Springer, T. A., D. Davignon, M.-K. Ho, K. Kurzinger, E. Martz, and F. Sanchez-Madrid. 1982. LFA-1 and Lyt-2,3, molecules associated with T lymphocyte-mediated killing; and Mac-1 and LFA-1 monologue associated with complement receptor function. Immunol. Rev. 68:171195.

59. Bianco, C., and V. Nussenzweig. 1977. Complement receptors. Contemp. Top. Mol. Immunol. 6:145-162.

60. Perlman, H., P. Perlman, R. D. Schreiber, and H. J. MullerEberhard. 1981. Interaction of target cell-bound C3bi and C3d with human lymphocyte receptors. Enhancement of antibody-mediated cellular cytotoxicity. J. Exp. Med. 153:1592-1600.

61. Beller, D. I., T. A. Springer, and R. D. Schreiber. 1979. AntiMac-1 selectively inhibits the mouse and human type three complement receptor. J. Exp. Med. 156:1000-1009.

62. Martz, E. 1977. Mechanism of specific tumor cell lysis by alloimmune T-lymphocytes: resolution and characterization of discrete steps in the cellular interaction. Contemp. Top. Immunobiol. 7:301.

63. Lay, W. R., and V. Nussenzweig. 1968. Receptors for complement on leukocytes. J. Exp. Med. 128:991.

64. Wright, S. D., and S. C. Silverstein. 1982. Tumor-promoting phorbol esters stimulate $\mathrm{C} 3 \mathrm{~b}$ and $\mathrm{C} 3 \mathrm{~b}^{\prime}$ receptor-mediated phagocytosis in cultured human monocytes. J. Exp. Med. 156:1149.

65. Banker, G. A., and C. W. Cotman. 1972. Measurement of free electrophoretic mobility and retardation coefficient of protein-sodium dodecyl sulfate complexes by cell electrophoresis. J. Biol. Chem. 247:5856-5881. 
66. Grefrath, S. D., and J. A. Reynolds. 1974. The molecular weight of the major glycoprotein from the human erythrocyte membrane. Proc. Natl. Acad. Sci. USA. 71:3913-3916.

67. Anderson, D., F. Schmalsteig, W. Shearer, M. Tosi, and S. Kohl. 1984. Studies of a new genetic disease characterized by a deficient PMN leukocyte surface glycoprotein(s). Pediatr. Res. 18:219A. (abstr.)

68. Beatty, P. B., H. D. Ochs, J. M. Harlan, T. H. Price, H. Rosen, R. F. Taylor, J. A. Hansen, and S. J. Klebanoff. 1983. Absence of a monoclonal antibody-defined protein complex in a boy with abnormal leukocyte function. Lancet. In press.

69. Fischer, A., B. Descamps-Latscha, I. Gerota, C. Scheinmetzier, J. I. Virelizner, P. Trung, B. L. Grospierri, N. Perez, A. Durandy, and C. Grischeili. 1983. Bone-marrow transplantation for inborn error of phagocytic cells associated with defective adherence, chemotaxis, and oxidative response during opsonized particle phagocytosis. Lancet. II:473476.

70. Hayward, A. R., J. Leonard, C. B. S. Wood, B. A. M. Harvey, M. C. Greenwald, and J. F. Southill. 1979. Delayed separation of the umbilical cord, widespread infection, and defective neutrophil mobility. Lancet. I:1326-1329.

71. Bissenden, J. G., M. R. Haeney, M. J. Tarlow, and R. A. Thompson. 1981. Delayed separation of the umbilical cord, severe widespread infections and immunodeficiency. Arch. Dis. Child. 56:397-399.

72. Davies, E. G., D. Isaacs, and R. J. Levinsky. 1982. Defective immune interferon production and natural killer activity associated with poor neutrophil mobility and delayed umbilical cord separation. Clin. Exp. Immunol. 50:454-460. 